\title{
TREATMENT OF EARLY VENEREAL SYPHILIS
}

\section{WITH ANTIBIOTICS*}

\author{
BY \\ R. R. WILLCOX \\ St. Mary's Hospital, London
}

Today, with the dawn of the space-age, there are few who would disagree with the remark of Professor Smelov (1956) at the First International Symposium on Venereal Diseases and Treponematoses in Washington, D.C., U.S.A., that "hardly any one doubts the curative power of penicillin against syphilis", or the opinion of Kinaçigil (1956) of Turkey expressed at the same meeting that penicillin is preferable to all other drugs in this condition. Since Mahoney and his colleagues first used this new antibiotic in the treatment of syphilis (Mahoney, Arnold, and Harris, 1943a, b, 1949), 18 years have passed and little has occurred to shake the faith of many thousands of doctors and of millions of patients in the potency of penicillin in this serious disease (see Döllken, 1954; Danbolt, 1954; Perdrup, Heilesen, and Sylvest, 1954; Shafer, Usilton, and Price, 1954) (Table I). Indeed, no other testimonial is required than the striking fall in the incidence of early syphilis which has occurred throughout the world.

TABLE I

RESULTS OF PENICILLIN THERAPY IN EARLY SYPHILIS (Data from Shafer and others, 1954)

\begin{tabular}{|c|c|c|c|c|c|c|}
\hline \multirow[b]{2}{*}{$\begin{array}{c}\text { Observa- } \\
\text { tion } \\
\text { Period } \\
\text { (mths) }\end{array}$} & \multicolumn{3}{|c|}{ Primary Syphilis } & \multicolumn{3}{|c|}{ Secondary Syphilis } \\
\hline & $\begin{array}{c}\text { No. of } \\
\text { Cases }\end{array}$ & $\begin{array}{c}\text { No. } \\
\text { Re- } \\
\text { treated }\end{array}$ & $\begin{array}{l}\text { Cumu- } \\
\text { lative } \\
\text { Per } \\
\text { cent. } \\
\text { Re- } \\
\text { treated }\end{array}$ & $\begin{array}{l}\text { No. of } \\
\text { Cases }\end{array}$ & $\begin{array}{c}\text { No. } \\
\text { Re- } \\
\text { treated }\end{array}$ & $\begin{array}{c}\text { Cumu- } \\
\text { lative } \\
\text { Per } \\
\text { cent. } \\
\mathrm{Re}- \\
\text { treated }\end{array}$ \\
\hline $\begin{array}{r}1 \\
6 \\
12 \\
24 \\
36 \\
48 \\
60 \\
72\end{array}$ & $\begin{array}{r}402 \\
396 \\
389 \\
381 \\
367 \\
331 \\
163 \\
81\end{array}$ & $\begin{array}{r}23 \\
9 \\
10 \\
1 \\
2 \\
1 \\
-\end{array}$ & $\begin{array}{r}\overline{5 \cdot 8} \\
8 \cdot 2 \\
10 \cdot 8 \\
11 \cdot 1 \\
11 \cdot 7 \\
12 \cdot 3 \\
12 \cdot 3\end{array}$ & $\begin{array}{l}961 \\
951 \\
927 \\
823 \\
730 \\
617 \\
315 \\
135\end{array}$ & $\begin{array}{r}\overline{51} \\
49 \\
35 \\
8 \\
5 \\
2 \\
\end{array}$ & $\begin{array}{r}\overline{5 \cdot 4} \\
11 \cdot 8 \\
14 \cdot 6 \\
15 \cdot 5 \\
16 \cdot 2 \\
16 \cdot 7 \\
16 \cdot 7\end{array}$ \\
\hline
\end{tabular}

- Paper presented at the W.H.O. Venereal Disease Travelling Seminar in the U.S.S.R.. September 8 to October 7, 1961.
This paper reviews some of the literature concerning penicillin and other antibiotics in the treatment of early syphilis, i.e. sero-negative primary syphilis, sero-positive primary syphilis, secondary syphilis, and early latent syphilis in the first year of infection (although in the U.S.A. the first four years are taken). The laboratory aspects, including the reorientation of ideas which has been made necessary by the advent of the Treponema Pallidum Immobilization test (TPI) and newer tests such as the Fluorescent Treponemal Antibody (FTA), have been reviewed separately by Nielsen (1961).

\section{Pre-penicillin Experience}

Before the discovery of penicillin, reliance had had to be placed on arsenic and bismuth therapy given over periods of approximately one year. The reported results for those patients who completed their treatment (see, for example, Burckhardt, 1949; Degos, Vissian, and Basset, 1950; Thompson and Smith, 1950; Arutyunov and Gurvich, 1958) in large series of cases were good and cure rates exceeding 90 per cent. were reported.

For example, Degos and others (1950) presented 1,340 cases of early syphilis treated in France and observed for an average of 11 years; only nine real failures were admitted, and four of these were probably reinfections.

One of the two great disadvantages of metallotherapy was that, because of the relatively weak treponemicidal powers of the drugs employed, prolonged treatment involving many injections was required, and default from treatment, and therefore absence of cure in those who defaulted, was very common. Indeed, a minimum curative dose might be received by only one quarter of the patients (Chope and Malcolm, 1948). The other disadvantage was the risk of serious toxic effects, which not only curtailed treatment in affected patients but, by 
reputation, encouraged other patients to default. At this time, therefore, case-holding, at least until the patient had received adequate therapy, was a very important aspect of venereal disease control.

During the second world war attempts were made to avoid the problem of default and some of the extra disadvantages of prolonged treatment under war-time conditions by using intensive schedules with arsenic and bismuth employing arsenoxide (or other pentavalent arsenical preparations-Beerman and Wammock, 1947) over short periods of 5 days by intravenous drip (Heller, 1946) or by repeated injections over 3 weeks (Pillsbury and Loveman, 1947), over 12 weeks (Weiner, 1947), over 26 weeks (Sternberg and Leifer, 1947a, b), and for even longer periods (Dexter, 1947). In general, the shorter the treatment period the lower the default rate, but the shorter the course the greater the risk of toxicity. Even the 20-day course, with which Pillsbury and Loveman (1947) had no fatality in 4,000 patients treated, was considered too toxic. For example, Cormia and Blauner (1947) noted that, although 95 per cent. of 500 patients (with few interruptions) completed a 20-day régime, there were two cases of arsenical encephalitis, fourteen of cerebral irritation, three of agranulocytosis, and six of jaundice.

The toxic effects of arsenic, not exerted by penicillin, and the relatively low spirochaeticidal activity of arsenic and bismuth preparations compared with the new and more potent penicillin, led to the gradual rejection of metallo-therapy. The most serious manifestations of toxicity due to arsenic were dermatitis (Moore, 1943; Stokes, Beerman, and Ingraham, 1944; Eagle and Magnuson, 1946; Pirilä, 1949); encephalopathy (Prebble, 1946; Parnitzke and Döhner, 1950); and agranulocytosis (Schoog, 1949). Other severe reactions were sometimes caused by Milian's ninth-day erythema (Neering, 1948; Reymann, 1948). Moreover, with the use of intravenous injections, syringe-transmitted jaundice became a considerable problem (Salaman, King, Williams, and Nicol, 1944; Laird, 1946; Willcox, 1947; Morton, 1948). Although deaths from metallo-therapy might occur only occasionally in some large series of several thousands of patients, individual experiences were often distressing. Pirilä (1949), in Finland, for example, reported eleven deaths in 385 patients treated over a period of 25 years - all these patients died from dermatitis, but four had liver damage and four had encephalopathy in addition.

Early Experiences with Penicillin

Mahoney and others (1943a) showed that peni- cillin was effective against syphilis both in experimental infection in the rabbit and also in man. This announcement was followed by an intensive cooperative study of the effects of penicillin in experimental syphilis in the rabbit (Moore, 1947) carried out in several laboratories in the U.S.A. In that country the work of Eagle, Mahoney, Chesney, Carpenter, Rake, Fleming, Magnuson, Rosahn, and Turner, and in Europe that of Ovchinnikov, Viaseleva, Levaditi, Vaisman, Bessemanns, Derom, and others, quickly enlarged the knowledge of the capabilities and limitation of the antibiotic (see Ovchinnikov, 1955).

Throughout, in the treatment of syphilis, penicillin has been given by injection. Oral therapy has too many disadvantages in comparison with parenteral treatment, although it is in fact possible to cure syphilis by this means, as also indeed by the use of penicillin rectal suppositories (Agneta and Molina, 1955).

\section{Amorphous Penicillin}

With low doses of 600,000 units and less, failure rates were shown to be high (Maillard and Orzel, 1946; Bauer, Bundesen, Craig, Schwemlein, and Barton, 1947, although very small doses would sometimes cure (Bellone, 1947). Reasonably good results were obtained with schedules of $2 \cdot 4$ mega units of aqueous solution given in sixty 3-hourly injections over $7 \frac{1}{2}$ days; the failure rates after one year varied between 6 and 17 per cent. depending upon the stage of the disease (Sternberg and Leifer, 1947; Arnold, Mahoney, Cutler, and Levitan, 1947b; Arnold, Boak, Carpenter, Chesney, Fleming, Gueft, Mahoney, and Rosahn, 1947a, although later assessments (see Moore, 1948) were not so optimistic, showing an overall failure rate of 25 to 35 per cent. after 2 years. There was no doubt that the results were better in primary than in secondary syphilis. Nevertheless, even those early schedules were strikingly successful in preventing the late complications of the disease. Altshuler, Karpinos, Leifer, and Ozog (1949) found only 21 abnormal spinal fluids in 30,972 patients previously treated with $2 \cdot 4$ mega units of penicillin. Such experience has been amply confirmed elsewhere with other schedules (Perdrup and Heilesen, 1956).

As soon as it became available, penicillin was soon in use for the treatment of syphilis throughout the world: e.g. in Great Britain (McElligott, 1948); in the U.S.S.R. (Arutyunov, Gurvich, and Ilina, 1948); in Germany (Hasselmann, 1949); and elsewhere. In the U.S.A. valuable data were quickly assembled by co-operative group studies involving 43 clinics and 
six laboratories, and these studies were later taken over by the United States Public Health Service (Moore, 1947).

\section{Crystalline Penicillin G}

As early as 1946 it became apparent in the U.S.A. that the results were deteriorating. Before May, 1944, a sero-negativity rate of 85 per cent. at 11 months had been achieved, but after that time the figure had fallen to only 60 per cent. (U.S. Public Health Service, 1946). Amorphous penicillin had by this time been shown to contain a number of fractions $(\mathrm{G}, \mathrm{F}, \mathrm{X}$, and $\mathrm{K})$ and laboratory work (e.g. by Carpenter, Boak, and Jacobs: 1946; Olansky and Putnam, 1946; Arnold and others, 1947a; and Turner, Cumberland, and $\mathrm{Li}, 1947$ ) had shown that penicillin $G$ was approximately ten times more effective than penicillin $\mathrm{K}$ in rabbit syphilis. Moreover, it was demonstrated that, in striving for a greater purity in unitage per milligramme, commercial penicillins had been containing progressively more and more of the $\mathrm{K}$ fraction.

Pure crystalline penicillin $G$ soon became commercially available and in a dosage of 2.4 to 4.8 mega units given in multiple injections every 2 to 4 hours for $7 \frac{1}{2}$ days or more, failure rates of 13 to 17 per cent. at 11 to 15 months were again recorded (Rider, 1949; Schwemlein, Plotke, and Rodriquez, 1950; Plotke, Rodriquez, and Schwemlein, 1951; Shafer and others, 1954) (Table I). Belenkii (1959) has presented 155 cases of early syphilis treated with $3,400,000$ units penicillin in 2 to 3 -hourly doses of 40,000 units. Unsuccessful results were noted in only 13.5 per cent., including two suspected re-infections, despite rigid tests of cure which included histological examination of the lymph nodes.

\section{Repository Penicillins}

\section{Penicillin in Oil-Beeswax}

The use of sixty or more injections of crystalline penicillin $G$ in aqueous solution within a period of $7 \frac{1}{2}$ days, if not more than the patients could reasonably tolerate, required their admission to hospital. The out-patient therapy of early syphilis became feasible only with the introduction by Romansky and Rittman (1945) of penicillin in oil-beeswax (containing 300,000 units calcium penicillin per $\mathrm{ml}$. arachis oil with $4 \cdot 8$ per cent. (u/v) beeswax per $\mathrm{ml}$ ). This enabled a continuous penicillinaemia to be maintained for 24 hours after an intramuscular injection of 600,000 units. Good results were reported with eight daily injections of 600,000 units (Romansky and Rein, 1946); Thomas, Landy and
Cooper, 1947); Chargin, Sobel, Rein, and Rosenthal, 1949; Bowden and Holmes, 1950; Lebioda, 1951), and success rates of 80 to 85 per cent. were achieved (Thomas, 1947, 1948a). By such means, nearly all patients could now achieve a curative dose (Hayman, 1947; Aitken, 1947), instead of only about onequarter as with arsenic and bismuth (Chope and Malcolm, 1948).

The principal disadvantage of penicillin in oilbeeswax was that it was of the consistency of soft butter and was therefore difficult to inject.

\section{Procaine Penicillin}

In Aqueous Suspension.-The discovery by Buckwalter and Dickison (1948) that procaine could be combined with penicillin, and that an aqueous suspension of the procaine salt would produce assayable serum levels for 24 hours or more after an injection of 300,000 units, provided a preparation as effective as penicillin in oil-beeswax but much easier to administer.

Eight daily injections of 600,000 units is acceptable therapy for primary, secondary and early latent syphilis (U.S. Publ. Hlth Service, 1960), but because penicillin it is so quickly eliminated when treatment is completed the treatment time has been extended by some clinicians (e.g. to 17 days by Feldreich, 1956) who have had excellent results. See also López and Rodriquez Morales (1955).

In Oil with Aluminium Monostearate (PAM).Procaine penicillin was further adapted by suspending it in arachis oil and gelling with 2 per cent. aluminium monostearate. Dose for dose, this compound provided high levels of penicillinaemia (for 72 hours or more after a test injection of 300,000 units). This was even better suited for the treatment of syphilis, as a continuous high serum level could be maintained if the patient missed an occasional injection. Moreover, the use of PAM enabled a reserve of penicillin to be built up within the body, which continued to act for a further week after the last injection.

Although less easy to administer than procaine penicillin, this preparation has proved to be the natural successor to penicillin in oil-beeswax and is now the most widely used throughout the world, not only for venereal syphilis but also for endemic syphilis and the other treponematoses, yaws and pinta (see Langer and Krüger, 1952; Gay Prieto, Alvares Cascos, and Orusco, 1953; Vilanova and Alvarado, 1953; Cutler, Olansky, and Price, 1955, for venereal syphilis: Murray, Merriweather, and Freedman, 1956; Grin, 1956, for endemic syphilis: Hackett and Guthe, 1956; Samame, 1956; Zahra, 
1956; Soetopo, Wasito, Soedarsono, and Tjokrodipo, 1956; Hume and Facio, 1956, for yaws: and Rein, Kitchen, Marquez, and Varela, 1952, for pinta: see also Guthe and Willcox, 1954).

By increasing the dose of PAM, the duration of the effective serum concentration (arbitrarily taken at 0.03 units $/ \mathrm{ml}$.) of penicillin can be prolonged, although the law of diminishing returns prevails insofar as an increase in the dose does not result in a proportionate prolongation of the effect. However, after an injection of 2.4 mega units, effective levels may be maintained for 8 to 10 days, and even 1.2 mega units may provide an effective level for more than one week (Table II).

TABLE II

PENICILLIN CONCENTRATION IN SERUM AND DURATION OF PENICILLINAEMIA ACCORDING TO DOSAGE OF PAM (Idsøe and others, 1954)

\begin{tabular}{c|c|c|c}
\hline \multicolumn{2}{c|}{$\begin{array}{c}\text { Single Injection } \\
\text { of PAM }\end{array}$} & $\begin{array}{c}\text { Duration of } \\
\text { Effective } \\
\text { Penicillinaemia } \\
\text { (days) }\end{array}$ & $\begin{array}{c}\text { Approximate } \\
\text { Penicillin } \\
\text { Concentration } \\
\text { in Serum after } \\
24 \mathrm{hrs} \\
\text { (units/ml.) }\end{array}$ \\
\hline ml. & units & $3-4$ & $0 \cdot 1$ \\
\hline 1 & 300,000 & $5-6$ & $0 \cdot 2$ \\
\hline 2 & 600,000 & $6-8$ & $0 \cdot 5$ \\
\hline 3 & $1,200,000$ & $7-10$ & $1 \cdot 0$ \\
\hline 4 & $2,400,000$ & & \\
\hline
\end{tabular}

This has prompted many studies, particularly in the U.S.A. on the treatment of syphilis with but one or two injections and excellent results have been reported by Thomas (1948b); Thomas, Rein, and Kitchen (1949); Thomas, Rein, Landy, and Kitchen (1950, 1951); Taggart, Hendricks, Chandler, Welch, Harley, and Olansky (1949); Wright, Nicholson, and Arnold (1950); Alexander, Schoch, and Mantooth (1950); Rodriquez, Schwemlein, and Plotke (1951); Parkhurst, Weinstein, and Rodriquez (1952); Jones and Heyman (1952); Barbosa Ribas, Marquesini, Russo, van Erven, Capriglione, and Pizzato (1955); Le Loutre (1955); Idsøe, Guthe, Christiansen, Krag, and Cutler (1954) (Table III). Consolidated data have suggested that "single-shot" techniques give a failure rate in secondary syphilis of only 10 per cent. at 15 months (Bauer, Usilton, and Price, 1950; Aufranc and Price, 1951) and of $14 \cdot 2$ per cent. at 21 months (Smith, O'Brien, Simpson, Harb, and Shafer, 1954). A minimum of $1 \cdot 2$ mega units has been recommended for primary syphilis and at least 2.4 mega units for secondary syphilis (Landy, Rein, and Thomas, 1956). Results are good even 4 to 8 years after treatment (Landy, Rein, Thomas, and Kelcec, 1957).

The use of single injection techniques has proved eminently suitable for the W.H.O.-assisted pro-
TABLE III

EXPECTED CURE RATES AFTER 2 YEARS IN SECONDARY SYPHILIS AFTER SINGLE INJECTIONS OF PAM (Adapted from Idsøe and others, 1954)

\begin{tabular}{c|c|c}
\hline Dose (units) & No. of Injections & $\begin{array}{c}\text { Cure Rate } \\
\text { (per cent.) }\end{array}$ \\
\hline 300,000 & 1 & $58 \cdot 5$ \\
\hline $1,200,000$ & 1 & $73 \cdot 4$ \\
\hline $2,400,000$ & 1 & $89 \cdot 3$ \\
\hline $4,800,000$ & 1 & $94 \cdot 6$ \\
\hline
\end{tabular}

grammes not only against venereal syphilis but particularly in mass campaigns against endemic syphilis and yaws. Graded single doses of PAM have been given to children and also to contacts whose treatment is essential to the success of such campaigns (Grin, 1953; Hackett and Guthe, 1956; Zahra, 1956). To date over 100 million persons have been examined, and over 30 million treated, in such campaigns, nearly all of them with PAM.

The W.H.O. Expert Committee on Venereal Infections and the Treponematoses (W.H.O., 1953) recommended that PAM should be used in the treatment of syphilis, a minimum dose of 2.4 mega units in primary syphilis and of 4.8 mega units in secondary syphilis. A number of schedules were suggested (Table IV) whereby the dosage could be spread over periods of from 1 to 17 days. It was also recommended that half the total dose (e.g. 1 2 mega units for primary and $2 \cdot 4$ for secondary syphilis) should be given at the first visit, so that should the patient default he would already have received the minimum curative, so-called epidemiological, dose. The United States Public Health Service recommend that, when PAM is used, 4.8 mega units should be given, usually as 2.4 mega units at the first injection with two subsequent injections each of 1.2 mega units 3 days apart for primary, secondary, and latent syphilis (U.S.P.H.S., 1960).

These "single-shot" techniques are best suited to the treatment of the masses, when the prime concern is to reduce infection in the population as a whole (Willcox, 1950a, b). In hospital practice many clinicians prefer multiple injection techniques, for which many variants of PAM are available to suit individual circumstances (Table IV).

If reliance is to be placed on one or on a few injections, it is essential that the PAM preparation should be up to standard. For many years, in conjunction with the United States Food and Drug Administration and the State Serum Institute, Copenhagen, W.H.O. has tested PAM preparations before use in the field. Not all the preparations submitted have proved satisfactory, and W.H.O. has 
drawn up certain specifications for PAM, the most important of which is that, 72 hours after a test injection of 300,000 units a serum level exceeding 0.03 units $/ \mathrm{ml}$. should be found in the majority of subjects. W.H.O. is stimulating research to evolve a better method of testing serum levels by the use of experimental animals instead of man.

\section{Benzathine Penicillin}

An even further prolongation of effective penicillinaemia, exceeding 0.03 units $/ \mathrm{ml}$. for 3 weeks and more, can be obtained with dibenzylethylenediamine penicillin (DBED; "Bicillin", "Penidural"; Bicillin I in the U.S.S.R.). If single injections are to be used, this is considered by many to be the preparation of choice. In the U.S.A., single injections of $2 \cdot 4$ mega units (1.2 mega units into each buttock) are recommended for both primary and secondary syphilis, although two such injections one week apart are suggested in latent cases (U.S.P.H.S., 1960). After $4 \cdot 8$ mega units of Soviet bicillin, therapeutic levels may be maintained for 15 to 30 days (Matveev, Khaimovsky, Levinstein, and Abdullaer, 1959).

Single injections of 2.4 to 2.5 mega units (Shafer and Smith, 1954; Smith and others, 1954; O'Brien and Smith, 1952; Smith, Kamp, Olansky, and Price, 1956) have shown that in secondary syphilis the retreatment rate at 2 years $(5 \cdot 5$ per cent.) was comparable with the 7.7 per cent. obtained with twice the single dose (i.e. $4 \cdot 8$ mega units) of PAM, and substantially better than the $14 \cdot 2$ per cent. at 21 months with the same dose (i.e. $2 \cdot 4$ mega units) (Table V). See also Castro and Bonatti (1957), Batunin, Kagan, Mikhailov, Nosyreva, and Khizkin (1959), Lesinska (1961), and Lebioda and Winiarski (1961).

TABLE V

SINGLE INJECTIONS OF BENZATHINE PENICILLIN AND PAM IN SECONDARY SYPHILIS

(Data from Smith and others, 1956)

\begin{tabular}{|c|c|c|c|c|}
\hline \multirow[b]{2}{*}{$\begin{array}{l}\text { Prepara- } \\
\text { tion }\end{array}$} & \multirow[b]{2}{*}{ Dosage } & \multirow{2}{*}{$\begin{array}{c}\text { No. } \\
\text { Treated }\end{array}$} & \multicolumn{2}{|c|}{ Results after 2 years } \\
\hline & & & $\begin{array}{l}\text { Cumulative } \\
\text { Per cent. } \\
\text { Retreated }\end{array}$ & $\begin{array}{c}\text { Percentage } \\
\text { Sero- } \\
\text { negative }\end{array}$ \\
\hline $\begin{array}{l}\text { Benza- } \\
\text { thine } \\
\text { Penicillin }\end{array}$ & $\begin{array}{l}2.5 \text { mega units in } \\
\text { one Injection... }\end{array}$ & 155 & $5 \cdot 5$ & $94 \cdot 5$ \\
\hline PAM & $\begin{array}{l}4.8 \text { mega units at } \\
\text { one Session }\end{array}$ & 166 & $7 \cdot 7$ & $91 \cdot 0$ \\
\hline
\end{tabular}

Benzathine penicillin (Bicillin I) has been widely used in Soviet co-operative studies. Altogether 9,410 injections have been given to 1,713 patients in the co-operating clinics (Rozentul, Vasilev, Egorow, Maslov, Khamaganova, and Rakhmanova, 1961). The short-term results are "fully satisfactory" (Batunin and others, 1959).

One disadvantage of benzathine penicillin is that it causes some local pain. This may occur in approximately half the patients, compared with less than

TABLE IV

SCHEDULES SUGGESTED BY W H.O EXPERT COMMITTEE FOR PAM DOSAGE SPECIMEN SYPHILIS-TREATMENT SCHEDULES-WITH PROCAINE PENICILLIN G IN OIL WITH 2 PER CENT. ALUMINIUM MONOSTEARATE (PAM)-FOR THE INDIVIDUAL CLINIC-PATIENT

\begin{tabular}{|c|c|c|c|c|c|c|c|c|c|c|c|c|c|c|c|c|c|}
\hline \multirow{2}{*}{ Syphilis } & \multicolumn{17}{|c|}{ Mega units of PAM to be given on the Following Days } \\
\hline & 1 & 2 & 3 & 4 & 5 & 6 & 7 & 8 & 9 & 10 & 11 & 12 & 13 & 14 & 15 & 16 & 17 \\
\hline Primary & $\begin{array}{l}2 \cdot 4 \\
1 \cdot 2 \\
1 \cdot 2 \\
1 \cdot 2 \\
1 \cdot 2 \\
1 \cdot 2 \\
1 \cdot 2 \\
1 \cdot 2 \\
1 \cdot 2\end{array}$ & $\begin{array}{l}\overline{-} \\
0 \cdot 6 \\
= \\
\overline{0} \cdot 3 \\
\overline{-}\end{array}$ & $\begin{array}{l}\text { 二 } \\
0.6 \\
0.6 \\
\overline{-} \\
0 \cdot 3 \\
0.3 \\
-\end{array}$ & $\begin{array}{l}Z \\
Z \\
\overline{0.6} \\
\overline{0 \cdot 3} \\
\overline{0 \cdot 3}\end{array}$ & $\begin{array}{l}\overline{1 \cdot 2} \\
\overline{0.6} \\
\overline{0.6} \\
0 \cdot 3 \\
0.3 \\
-\end{array}$ & $\begin{array}{l}E \\
\bar{E} \\
\bar{E} \\
\bar{E}\end{array}$ & $\begin{array}{l}\bar{Z} \\
\overline{-} \\
\overline{0.6} \\
\overline{-} \\
0 \cdot 3 \\
0.3\end{array}$ & $\begin{array}{l}\bar{Z} \\
\overline{-} \\
\overline{-} \\
\overline{-}\end{array}$ & $\begin{array}{l}\text { 二 } \\
\text { 二 } \\
\overline{0.6} \\
\overline{0.3} \\
-\end{array}$ & $\begin{array}{l}\bar{Z} \\
\bar{Z} \\
\bar{Z} \\
\overline{0}\end{array}$ & $\begin{array}{l}E \\
= \\
\overline{-} \\
= \\
=\end{array}$ & $\begin{array}{l}= \\
= \\
= \\
= \\
=\end{array}$ & $\begin{array}{l}\bar{Z} \\
\bar{Z} \\
\bar{Z} \\
\overline{0 \cdot 3}\end{array}$ & $\begin{array}{l}= \\
= \\
= \\
= \\
=\end{array}$ & $\begin{array}{l}= \\
= \\
= \\
= \\
=\end{array}$ & $\begin{array}{l}= \\
= \\
= \\
=\end{array}$ & $\begin{array}{l}= \\
= \\
= \\
= \\
=\end{array}$ \\
\hline Secondary & $\begin{array}{l}4 \cdot 8 \\
2 \cdot 4 \\
2 \cdot 4 \\
2 \cdot 4 \\
2 \cdot 4 \\
2 \cdot 4 \\
2 \cdot 4 \\
2 \cdot 4 \\
2 \cdot 4 \\
2 \cdot 4 \\
2 \cdot 4\end{array}$ & $\begin{array}{l}\bar{Z} \\
\overline{1 \cdot 2} \\
\bar{Z} \\
\overline{0 \cdot 6} \\
\overline{-} \\
\overline{0.3}\end{array}$ & $\begin{array}{l}\overline{-} \\
\overline{1.2} \\
1.2 \\
\overline{-} \\
\overline{0.6} \\
0.6 \\
\overline{0 \cdot 3} \\
0.3\end{array}$ & $\begin{array}{l}\bar{Z} \\
\bar{Z} \\
\overline{1 \cdot 2} \\
\overline{0.6} \\
\overline{0.6} \\
0.3 \\
-\end{array}$ & $\begin{array}{l}\overline{2 \cdot 4} \\
\overline{1 \cdot 2} \\
\overline{1 \cdot 2} \\
0 \cdot 6 \\
0 \cdot 6 \\
\overline{0 \cdot 3} \\
0 \cdot 3\end{array}$ & $\begin{array}{l}\bar{z} \\
\bar{z} \\
\bar{z} \\
\bar{z} \\
\overline{0}-3\end{array}$ & $\begin{array}{l}\text { 二 } \\
\bar{Z} \\
1 \cdot 2 \\
\bar{Z} \\
0 \cdot 6 \\
0 \cdot 6 \\
0 \cdot 3 \\
0 \cdot 3\end{array}$ & $\begin{array}{l}z \\
\bar{z} \\
\bar{z} \\
\bar{z} \\
\overline{0} \\
-\end{array}$ & $\begin{array}{l}\text { 二 } \\
\text { 二 } \\
\overline{1 \cdot 2} \\
\overline{0 \cdot 6} \\
\overline{0 \cdot 3} \\
0 \cdot 3\end{array}$ & $\begin{array}{l}= \\
= \\
= \\
\bar{z} \\
\overline{0.6} \\
=\end{array}$ & $\begin{array}{l}\bar{Z} \\
\bar{z} \\
\bar{z} \\
\bar{z} \\
\overline{0}\end{array}$ & $\begin{array}{l}= \\
= \\
= \\
= \\
= \\
=\end{array}$ & $\begin{array}{l}= \\
\bar{Z} \\
\bar{Z} \\
\bar{z} \\
\overline{0.6} \\
\overline{0.3}\end{array}$ & $\begin{array}{l}= \\
= \\
= \\
= \\
= \\
=\end{array}$ & $\begin{array}{l}= \\
= \\
= \\
= \\
\bar{z} \\
\overline{0 \cdot 3}\end{array}$ & $\begin{array}{l}= \\
= \\
= \\
= \\
= \\
=\end{array}$ & $\begin{array}{l}= \\
= \\
= \\
= \\
= \\
0.3\end{array}$ \\
\hline
\end{tabular}


5 per cent. of those treated with procaine penicillin (Krugman and Ebin, 1958; Gallego, 1956). This objection also applies to Soviet bicillin (Matveev and others, 1959; Batunin and others, 1959). Pain can be reduced, however, by mixing the benzathine penicillin with procaine penicillin (Krugman and Ebin, 1958). On the other hand, the risks of allergic reactions to penicillin are reduced when singleinjection techniques are used (Smith and others, 1956). In the U.S.S.R., Bicillin III (containing benzyl penicillin, procaine penicillin, and benzathine penicillin) has been used on a co-operative basis by multiple injections and has been shown to be better tolerated than benzathine penicillin (Bicillin I) alone (Rozentul and others, 1961). This is equivalent to the British and American so-called "all-purpose" penicillins.

\section{Mixed - Treatment}

When penicillin was first introduced, there was a reluctance in many countries to accept the new antibiotic as the sole curative agent in the treatment of syphilis and to reject immediately and completely the old, well-tried methods. This was particularly true in Europe, where a compromise was attempted, using penicillin and one course of the older arsenic and bismuth therapy, or a shortened course with arsenoxide. In Great Britain these combinations were used in many clinics (Harrison, 1945; Eames and Archer, 1947; McElligott, Jefferiss, and Willcox, 1948; Eames and Miller, 1949); in France penicillin, arsenic, and bismuth were tried by Marin, Boulais, Lambert, Foisy, and Leclerc (1949), and penicillin, mercury, and bismuth by des Roseaux (1949); in Poland (Rosner, 1950; Ryll Nardzewski, 1950; Pietrowska, 1956; Sokolowski, 1950); in Scandinavia (Danbolt and Berdal, 1950); in the U.S.S.R. (Smelov, 1957). Such régimes were also followed in parts of the U.S.A. (Alexander and others, 1950; Chargin, Sobel, and Rosenthal, 1951); in South Africa (O'Malley, 1950); in Asia (Lozano, 1950). In France the use of penicillin has been preceded by intravenous injections of mercury cyanide (Bolgert and Lévy, 1957a, b), and in the U.S.S.R. penicillin has been used in conjunction with fever therapy (Khokhutin, 1956). Iodine has also been used in conjunction with penicillin (Loza, 1950; Kapuściński, 1950).

However, with mixed treatment the risk of toxic reactions, particularly from arsenic, remained. Heller, Bowman, and Price (1948) reported that there were no deaths and 240 treatment reactions in 33,724 patients treated with penicillin alone, while in 118,544 patients given penicillin and arsenoxide there were sixteen deaths and 1,632 severe reactions.
Even in 1953-1954, fatalities from toxicity of arsenotherapy were still being reported in Europe (Edmunds, 1954; Fazekas and Dósa, 1954; Höfer and Heilmann, 1953). Arsenic was then gradually discarded (Gurevich, Kamenetski, and Litvak, 1958) but penicillin and bismuth continued to be used. For example, in Great Britain (Jefferiss, Willcox, and McElligott, 1951), in parts of the U.S.A. (Pardo and Pardo Castello, 1952; Pardo, 1956), in Belgium (Alechinsky, 1949), in France (Huriez, 1956), in India (Gault, 1955), in Germany (Schmidt-La Baume and Thélen, 1953), in Hungary (Helmeczi, Máramarosi, and Fekete, 1955), in Poland (Capiński, 1961; Pawlas and Golebiowska, 1950; Towpik, 1950; Walter, Capiński, Lejman, and Lebioda, 1950), in the U.S.S.R. (Gurevich and others, 1958), and elsewhere (Carrera, 1955b). In the U.S.S.R., Ovchinnikov and Kuchinskaya (1948) reported that the admixture of penicillin and bismuth before injection had a retarding effect on the absorption of penicillin.

Combined treatments were encouraged by reports of synergism between penicillin and arsenic and bismuth, with and without fever, in experimental syphilis (Magnuson and Rosenau, 1948; Levaditi and Vaisman, 1950), and some authors (Leavitt, 1947; Jones, 1951; Towpik, 1956; Czernielewski and Olszewska, 1961) reported slightly better results with combined treatment than with penicillin alone, although it is likely this apparent superiority was due to the longer treatment period and suppression of re-infection rather than to a lower incidence of relapse. Statistically-controlled surveys have shown no advantages in adding other drugs to penicillin (Heller and others, 1948; Thomas and Gleeson, 1953; Shafer and others, 1954; Tempski and Olszewska, 1954; Pietrowska, 1956; McElligott and Willcox, 1957) (Tables VI, VII, VIII, and IX, opposite).

Indeed, Towpik (1961) has pointed out that the apparently favourable influence of additional arsenic and bismuth is only noted when the initial penicillin dosage has been too low. Certainly, treatment with penicillin alone with few injections most closely approaches the ideal therapy as regards therapeutic efficiency, low toxicity, low mortality, and low cost (Table X, overleaf).

\section{W.H.O. Survey of Treatment Practices}

In 1953 W.H.O. undertook a study of the treatment practices in early syphilis in 277 venereal disease clinics throughout the world (Willcox, 1954a). Penicillin alone was used in $65 \cdot 3$ per cent. of all clinics, in 100 per cent. in North America, in $64 \cdot 1$ to $65 \cdot 2$ per cent. in Central and South America and 
TABLE VI

COMPARISON OF PENICILLIN ALONE, PENICILLIN WITH BISMUTH, AND PENICILLIN WITH ARSENIC AND BISMUTH (McElligott and Willcox, 1957)

\begin{tabular}{|c|c|c|c|c|}
\hline \multicolumn{2}{|c|}{ Preparation } & $\begin{array}{l}\text { Penicillin } \\
\text { with } \\
\text { Arsenic } \\
\text { and } \\
\text { Bismuth }\end{array}$ & $\begin{array}{l}\text { Penicillin } \\
\text { with } \\
\text { Bismuth }\end{array}$ & $\begin{array}{l}\text { Penicillin } \\
\text { Alone }\end{array}$ \\
\hline \multicolumn{2}{|c|}{ Length of Course (wks) } & 11 & 11 & 6 \\
\hline No. Treated .. & . & 561 & 183 & 120 \\
\hline $\begin{array}{l}\text { Followed One } \\
\text { Year or More }\end{array}$ & $\begin{array}{l}\text { No. . . } \\
\text { Per cent. }\end{array}$ & $\begin{array}{r}307 \\
54 \cdot 5\end{array}$ & $\begin{array}{c}76 \\
41 \cdot 5\end{array}$ & $\begin{array}{c}56 \\
46 \cdot 7\end{array}$ \\
\hline \multicolumn{2}{|c|}{$\begin{array}{l}\text { Per cent. Failures of Those } \\
\text { Followed One Year or More }\end{array}$} & $7 \cdot 2$ & $9 \cdot 2$ & $3 \cdot 6$ \\
\hline
\end{tabular}

TABLE VII

PERCENTAGE CUMULATIVE RETREATMENT RATES IN CASES OF SECONDARY SYPHILIS GIVEN PENICILLIN, ARSENOXIDE AND BISMUTH WITH PENICILLIN, AND ARSENIC AND BISMUTH WITHOUT PENICILLIN (Data from Shafer and others, 1954)

\begin{tabular}{|c|c|c|c|}
\hline \multirow{2}{*}{$\begin{array}{l}\text { Length of } \\
\text { Observation } \\
\text { (mths) }\end{array}$} & \multicolumn{3}{|c|}{ Preparation } \\
\hline & $\begin{array}{l}\text { Arsenic and } \\
\text { Bismuth }\end{array}$ & $\begin{array}{l}\text { Penicillin } \\
\text { plus Arsenic } \\
\text { and Bismuth }\end{array}$ & $\begin{array}{l}\text { Penicillin } \\
\text { Alone }\end{array}$ \\
\hline $\begin{array}{r}0 \\
6 \\
12 \\
24 \\
36 \\
48 \\
60 \\
72 \\
84 \\
96\end{array}$ & $\begin{array}{r}2 \cdot 8-6 \cdot 9 \\
10 \cdot 0-17 \cdot 7 \\
19 \cdot 9-29 \cdot 9 \\
23 \cdot 3-33 \cdot 4 \\
25 \cdot 2-36 \cdot 3 \\
26 \cdot 3-37 \cdot 5 \\
26 \cdot 3-37 \cdot 5 \\
29 \cdot 4-40 \cdot 8 \\
33 \cdot 6-49 \cdot 6\end{array}$ & $\begin{array}{l}\overline{4} \cdot 5 \\
12 \cdot 0 \\
16 \cdot 0 \\
16 \cdot 0 \\
16 \cdot 8 \\
17 \cdot 4 \\
17 \cdot 4 \\
\text { NR } \\
\text { NR }\end{array}$ & $\begin{array}{l}\overline{5 \cdot 6} \\
11 \cdot 5 \\
13 \cdot 7 \\
15 \cdot 1 \\
15 \cdot 9 \\
16 \cdot 3 \\
16 \cdot 3 \\
\text { NR } \\
\text { NR }\end{array}$ \\
\hline Total No. of & 147 & 292 & 679 \\
\hline
\end{tabular}

TABLE IX

SERO-REVERSAL AFTER PENICILLIN TREATMENT OF EARLY SYPHILIS

(Data from Perdrup, 1960)

(a) To Conventional Serum Tests (171 cases)

\begin{tabular}{c|c|c|c}
\hline $\begin{array}{c}\text { Months from } \\
\text { Treatment }\end{array}$ & $\begin{array}{c}\text { Patients } \\
\text { Sero-negative }\end{array}$ & $\begin{array}{c}\text { Cumulative } \\
\text { Negative } \\
\text { Results }\end{array}$ & $\begin{array}{c}\text { Per cent. } \\
\text { STS-Negative }\end{array}$ \\
\hline $1-10$ & 133 & 133 & $77 \cdot 8$ \\
$11-20$ & 21 & 154 & $90 \cdot 1$ \\
$21-30$ & 9 & 163 & $95 \cdot 3$ \\
$31-40$ & 3 & 166 & $97 \cdot 1$ \\
$41-50$ & 2 & 168 & $98 \cdot 2$ \\
$50+$ & 3 & 171 & $100 \cdot 0$ \\
\hline
\end{tabular}

\section{(b) To TPI Test (88 cases)}

\begin{tabular}{c|c|c|c}
\hline \multirow{2}{*}{$\begin{array}{c}\text { Years from } \\
\text { Treatment }\end{array}$} & $\begin{array}{c}\text { No. of Patients } \\
\text { Tested }\end{array}$ & \multicolumn{2}{|c}{ Negative Results } \\
\cline { 3 - 4 } & & No. & Per cent. \\
\hline 2 & 88 & 62 & $70 \cdot 5$ \\
3 & 82 & 56 & $68 \cdot 3$ \\
4 & 80 & 55 & $68 \cdot 8$ \\
5 & 75 & 51 & $68 \cdot 0$ \\
6 & 66 & 46 & $69 \cdot 7$ \\
7 & 50 & 35 & $70 \cdot 0$ \\
8 & 30 & 19 & $63 \cdot 3$ \\
9 & 18 & 13 & $72 \cdot 2$ \\
10 & 6 & 4 & $66 \cdot 7$ \\
\hline
\end{tabular}

TABLE VIII

PERCENTAGE CUMULATIVE RETREATMENT RATES IN CASES OF SERO-POSITIVE EARLY SYPHILIS GIVEN PENICILLIN ALONE AND PENICILLIN WITH ARSENIC AND BISMUTH

(Towpik, 1961)

\begin{tabular}{|c|c|c|c|c|c|c|c|c|}
\hline \multirow[b]{2}{*}{ Schedule } & \multirow[b]{2}{*}{ Years } & \multicolumn{2}{|c|}{ Penicillin } & \multirow{2}{*}{$\begin{array}{c}\text { Duration } \\
\text { (days) }\end{array}$} & \multirow{2}{*}{$\begin{array}{c}\text { No. } \\
\text { Treated }\end{array}$} & \multicolumn{3}{|c|}{ Cumulative Percentage Retreated } \\
\hline & & Preparation & $\begin{array}{c}\text { Dosage } \\
\text { (mega units) }\end{array}$ & & & At $12 \mathrm{mths}$ & At $24 \mathrm{mths}$ & At $60 \mathrm{mths}$ \\
\hline \multirow{4}{*}{ Penicillin alone } & $1947-1948$ & Crystalline penicillin & $2 \cdot 4-3 \cdot 0$ & $7 \frac{1}{2}-8$ & 85 & $13 \cdot 2$ & $20 \cdot 6$ & $20 \cdot 6$ \\
\hline & 1948-1949 & РOB & $4 \cdot 8-6 \cdot 0$ & $12-20$ & 59 & $5 \cdot 2$ & $7 \cdot 1$ & $7 \cdot 1$ \\
\hline & 1949-1951 & PAM & $3 \cdot 0$ & 10 & 123 & $31 \cdot 4$ & $33 \cdot 2$ & $33 \cdot 2$ \\
\hline & 1954-1955 & Procaine penicillin. & $6 \cdot 0$ & 20 & 138 & $15 \cdot 7$ & $19 \cdot 3$ & $24 \cdot 3$ \\
\hline \multirow{2}{*}{$\begin{array}{l}\text { Penicillin with } \\
\text { Arsenic and } \\
\text { muth } \quad \ldots \\
\text { mus- }\end{array}$} & 1947-1948 & Crystalline penicillin & $2 \cdot 4-3 \cdot 0$ & $?$ & 238 & $8 \cdot 1$ & $10 \cdot 0$ & $11 \cdot 7$ \\
\hline & $1948-1949$ & РOB & $4 \cdot 2$ & $?$ & 94 & $12 \cdot 6$ & $12 \cdot 6$ & $17 \cdot 2$ \\
\hline
\end{tabular}


Asia, but in only $52 \cdot 2-56 \cdot 3$ per cent. in the Eastern Mediterranean region and Europe, where there was a much greater reluctance to grasp the new concepts of treatment. In 28.9 per cent. of clinics $(47.8$ per cent. in Europe) arsenical and bismuth drugs were still being used in conjunction with penicillin, but in only 5.8 per cent. was arsenic and bismuth treatment without penicillin still in use (Carrera, 1955a). This same reluctance was also noted in respect of the use of the epidemiological dose of penicillin. Whereas for secondary syphilis in North America in 46.4 per cent. of clinics a first dose of 2.4 mega units or more (and in 60.7 per cent. of 1.2 mega units or more) was given, in Asia in 75.3 per cent. of clinics an initial dose of 1.2 mega units or more, and in Europe a first dose exceeding 0.9 mega units was administered in only 12.5 per cent. of clinics. It is considered likely, on the basis of more recently expressed opinions (e.g. Rollier, 1957), that a new survey would show that more and more European physicians had by now changed to the practice of using penicillin alone.

Even as late as 1949 Veyre and Baylet (1949), in France, still conceived the treatment of syphilis in the following stages:

(1) Treatment of attack-one year;

(2) Treatment of consolidation 2-3 years;
(3) After-control and treatment of insurance 3-4 years;

(4) Observation for life.

With penicillin the period of the treatment of attack is reduced to less than 17 days, and no consolidation or treatment of insurance has been shown to be necessary. Observation for 2 to $2 \frac{1}{2}$ years is, however, usually insisted upon (Belden, 1956), although in some centres, e.g. the United States Public Health Service clinics, this period has been reduced to 18 months. If only one cerebrospinal fluid examination is made in early syphilis it is recommended that it is best done after a lapse of 12 months (U.S.P.H.S., 1960).

The retention of the concept of consolidation led (particularly in Europe and more especially in the United Kingdom) first to the retention of arsenic and bismuth and then of bismuth only in addition to penicillin. When bismuth was finally discarded some clinics used further penicillin for consolidation, giving ten bi-weekly injections of $0 \cdot 9-1 \cdot 2$ mega units PAM as a supplement to the intensive penicillin course. In the W.H.O. survey referred to above, penicillin was used in this way in secondary syphilis in approximately one-quarter of European clinics. Indeed, up to five penicillin courses are used in some places, e.g. in Hungary (Földvari, 1961) and in the U.S.S.R. (Rozentul and others, 1961). This

TABLE X

COMPARISON OF THERAPEUTIC EFFICIENCY, SIDE-REACTIONS, AND COST OF SCHEDULES OF TREATMENT USED FOR EARLY SYPHILIS (Guthe and Willcox, 1954)

\begin{tabular}{|c|c|c|c|c|c|c|c|c|}
\hline \multirow{2}{*}{\multicolumn{2}{|c|}{ Assessment Factor }} & \multirow[b]{2}{*}{$\begin{array}{l}\text { Ideal } \\
\text { Therapy }\end{array}$} & \multicolumn{2}{|c|}{ Metal Chemotherapy } & \multicolumn{2}{|c|}{ Combined Therapy } & \multicolumn{2}{|c|}{ Penicillin Alone } \\
\hline & & & $\begin{array}{l}\text { Neoarsphena- } \\
\text { mine and } \\
\text { Bismuth. } \\
\text { (Four 3-month } \\
\text { Courses of } \\
\text { ten Injections } \\
\text { Each) }\end{array}$ & $\begin{array}{c}\text { Arsenoxide } \\
\text { (1,200 mg. by } \\
\text { Intravenous } \\
\text { Drip over } \\
5 \text { days })\end{array}$ & $\begin{array}{c}\text { Amorphous } \\
\text { Aqueous } \\
\text { Penicillin } \\
\text { (5 mega units) } \\
\text { Arsenoxide } \\
\text { (36-450 mg.) } \\
\text { Bismuth } \\
\text { (6-12 Injections) }\end{array}$ & $\begin{array}{c}\text { Penicillin } \\
\text { in Oil-Beeswax } \\
\text { or with } \\
\text { Aluminium } \\
\text { Monostearate } \\
\text { (4.8 mega units) } \\
\text { Bismuth } \\
\text { (ten Injections) }\end{array}$ & $\begin{array}{c}\text { Procaine } \\
\text { Penicillin G } \\
\text { with } \\
\text { Aluminium } \\
\text { Monostearate } \\
\text { (4.8 mega units) }\end{array}$ & $\begin{array}{c}N^{\prime} \mathbf{N}^{\prime} \\
\text { Dibenzylethylene- } \\
\text { diamine } \\
\text { dipenicillin } G \\
(2 \cdot 5 \text { mega units })\end{array}$ \\
\hline \multicolumn{2}{|c|}{ Therapeutic Efficacy $^{1}$. } & 100 & $91 \cdot 5$ & $90 \cdot 0$ & $91 \cdot 8^{8}$ & $86 \cdot 4$ & $91 \cdot 3$ & $94 \cdot 0^{7}$ \\
\hline \multirow{2}{*}{ Toxicity } & $\begin{array}{l}\text { Side- } \\
\text { reactions }{ }^{2}\end{array}$ & 0 & $9 \cdot 5$ & $8 \cdot 5$ & $8 \cdot 0$ & $\pm 5 \cdot 0$ & $\pm 5 \cdot 0$ & $0 \cdot 3-1 \cdot 0$ \\
\hline & Mortality $^{3}$ & 0 & 0.033 & 0.5 & 0.014 & 0.014 & 0.014 & 0.014 \\
\hline \multicolumn{2}{|c|}{$\begin{array}{l}\text { Convenience of } \\
\text { Administration }\end{array}$} & 100 & $\begin{array}{c}50+ \\
\text { (ambulant) }\end{array}$ & $\begin{array}{c}90 \\
\text { (hospital) }\end{array}$ & $\begin{array}{c}65 \\
\text { (hospital and } \\
\text { ambulant) }\end{array}$ & $\begin{array}{c}75+ \\
\text { (ambulant) }\end{array}$ & $\begin{array}{c}95-100 \\
\text { (ambulant) }\end{array}$ & $\begin{array}{c}95-100 \\
\text { (ambulant) }\end{array}$ \\
\hline \multicolumn{2}{|c|}{ Drug Cost ${ }^{\mathrm{s}}$} & - & $58 s .8 d$. & $35 s$. & $15 s .6 d$. & 8s. $6 d$. & 7s. $2 d$. & . $8 s .5 d$ \\
\hline
\end{tabular}

* Based on data from the U.S. Public Health Service, the British Clinical Co-operative Group, and the University Dermatological Clinic, Oslo.

1 Percentage of apparent cures at 24 months if the full course is given, and adjusted for estimated re-infections in the case of penicillin schedules with no adjuvant therapy.

Percentage of serious side-reactions.

- Percentage of deaths due to treatment.

- Percentage of patients completing prescribed course of therapy.

- Drug cost to clinics in Great Britain in shillings and pence at 1960 prices.

${ }^{6}$ Includes sero-negative and sero-positive early syphilis.

'21 months' follow-up. 
may be regarded either as consolidation or as prolongation of treatment time to 6 weeks. The principal advantage of such treatment is that it is more than sufficient for all forms of syphilis and, in small clinics where daily treatment is not easy to organise, it can-by the omission of the preliminary daily course-be readily given to patients attending only twice weekly. The results have been better than with penicillin and bismuth, with or without arsenic, probably by reducing the number of re-infections by the use of a longer treatment period with the most potent drug (penicillin). (Table XI).

\section{Time-Dose Relationship}

Although T.pallidum is one of the most penicillinsensitive organisms known (Idsøe and others, 1954), and as little as 0.0025 units $/ \mathrm{ml}$. will immobilize 50 per cent. of treponemes within 16 hours (Magnuson, 1952), exposure for a longer time is required to kill it. The multiplication time of $T$. pallidum in vivo is calculated at 30 to 33 hours (Magnuson and others, 1948; Cumberland and Turner, 1949), but, to allow a safety margin, penicillin-free intervals should not be permitted for more than 24 hours during therapy.

The height of the serum penicillin level over an arbitrary minimum (usually taken at 0.03 units $/ \mathrm{ml}$.) is not important (Eagle, 1948) but its duration is. Although the duration of the penicillinaemia is related to dosage of the same preparation, widely differing durations are obtained dose-for-dose, varying from a few hours with aqueous crystalline penicillin to weeks with benzathine penicillin; it is nonsensical, therfore, to regard the treatment of syphilis as "so many units of penicillin" without reference to the particular preparation employed.

The earlier the infection the smaller the time/dose combination required. With sero-negative primary syphilis only 300,000 units of PAM (giving an effective level for 72 to 96 hours) will cure over 90 per cent. of cases (Idsøe and others, 1954; Walker and Utterback, 1949), and a deliberate exposure for 4 to 7 days has been considered sufficient for this early stage. But minimal doses which will cure seronegative early syphilis are less effective in seropositive primary and especially secondary syphilis, in which higher failure rates are observed when schedules with a narrow safety margin are used (Cutler and others, 1955; Tempski and Olszewska, 1954; Prochacki, Smolska, Dobosiewicz, Hawryluk, and Tarchalska, 1961 ; Lejman, Bittner, Korturkowa, and Logdaszewska-Czabanowska, 1961) (Table XI). From the practical standpoint it is best to gear the treatment of all cases of early syphilis to that required for secondary syphilis, although, when cost of the drug is a major consideration, a reduced amount of penicillin in primary syphilis is sometimes permissible.

The required time/dose aggregate of penicillin in early syphilis thus depends on the duration of the disease and therefore also on the number of spirochaetes in the body. If small doses will cure overt primary syphilis, even less should be needed in the incubation period. The use of small doses of PAM (Willcox, 1961) is very successful in curing unrecognized pre-primary syphilis in patients suffering from gonorrhoea. If small doses of penicillin will completely abort incubating syphilis in patients who are unfortunate enough to contract gonorrhoea, it will do so equally well in contacts without gonorrhoea if seen equally soon after exposure.

\section{Relapses and Re-infections}

Isolated cases of tertiary lesions following the penicillin treatment of syphilis (Degos, Garnier, and Delzant, 1958) are reported from time to time. Their

TABLE XI

PERCENTAGE FAILURE RATES ACCORDING TO STAGE OF EARLY SYPHILIS

\begin{tabular}{|c|c|c|c|c|c|c|c|c|c|}
\hline Author $\quad$. & $\cdots$ & $\cdots$ & $\cdots$ & $\cdots$ & $\cdots$ & $\begin{array}{l}\text { Tempski and } \\
\text { Olzewska }\end{array}$ & Prochacki and Others & Lejman and Others & Capiński \\
\hline Date & $\cdots$ & $\cdots$ & $\ldots$ & $\cdots$ & $\cdots$ & 1954 & 1961 & 1961 & 1961 \\
\hline No. of Cases & $\cdots$ & $\cdots$ & $\cdots$ & $\cdots$ & $\cdots$ & 621 & 745 & 501 & $66^{*}$ \\
\hline Treatment & $\cdots$ & . & $\cdots$ & . & $\cdots$ & $\begin{array}{c}\text { Pen. alone. } \\
\text { Pen., As, and Bi. }\end{array}$ & $\begin{array}{l}\text { Pen. alone. } \\
\text { Pen., As, and Bi. }\end{array}$ & $\begin{array}{l}\text { Pen. alone. } \\
\text { Pen., As, and Bi }\end{array}$ & Pen., As, and Bi. \\
\hline \multicolumn{4}{|c|}{ Dose of Penicillin (mega units) } & $\cdots$ & $\cdots$ & $3-8 \cdot 4$ & $3-6$ & $2 \cdot 4-6$ & $2 \cdot 4$ \\
\hline \multicolumn{3}{|c|}{ Pailure Rate (per cent.) } & $\cdots$ & . & $\cdots$ & $4 \cdot 4$ & nil & - & - \\
\hline $\begin{array}{l}\text { Stage of } \\
\text { Early } \\
\text { Syphilis }\end{array}$ & \multicolumn{4}{|c|}{$\begin{array}{l}\text { Sero-negative Primary } \\
\text { Sero-positive Primary } \\
\text { Secondary .. } \\
\text { Relapsing Secondary }\end{array}$} & $\begin{array}{l}\cdots \\
\cdots \\
\cdots\end{array}$ & $\begin{array}{r}4 \cdot 4 \\
6 \cdot 4 \\
14 \cdot 3 \\
\text { higher }\end{array}$ & $\begin{array}{l}\text { nil } \\
5 \cdot 7 \\
5 \cdot 9 \\
13 \cdot 3\end{array}$ & $\begin{array}{c}\text { nil } \\
1 \cdot 8 \\
7 \cdot 1 \\
15 \cdot 6\end{array}$ & $\begin{array}{c}\text { nil } \\
\text { nil } \\
12 \cdot 2 \dagger \\
?\end{array}$ \\
\hline
\end{tabular}


very rarity makes them worthy of record. The usual treatment failures are cases of clinical, serological, or neurological relapse noted within the first yearusually within the first 6 months-or cases of seroresistance at 6-12 months (Downing, 1950; Peabody and Webster, 1949; Sackett and Boggs, 1949). Persistent serological abnormalities are frequently associated with neurological involvement (Prochacki, 1953). The Nelson test has required some reappraisal of the serological cure of syphilis. Lesinska (1961) found that the reaction became negative within 6-18 months in about two-thirds of patients with early syphilis, more commonly in primary syphilis, but that constant positive results should not be regarded as due to treatment failure (see also Nielsen, 1961). In the data of Perdrup (1960)-see Table IX-approximately 30 per cent. of patients tested 2 to 10 years after treatment still had a positive TPI test. There was little or no tendency for the positivity rates to improve with the years, whereas, with conventional serum tests, seronegativity was achieved in 10 months in 77.8 per cent. of cases, 11-20 months in $90 \cdot 1$ per cent., and in approximately 4 years in $98 \cdot 2$ per cent.

It is frequently very difficult to distinguish relapse from re-infection (Schamberg and Steiger, 1948; Schamberg, 1950), and a patient rapidly cured of syphilis with penicillin can also rapidly be re-infected. Careful consideration of many of the so-called early relapses following penicillin therapy has indicated that many, indeed up to one-half and more of so-called failures, are in fact re-infections (Thomas and Landy, 1950; Schoch and Alexander, 1949; Rajam, Krishnamurthi, and Rangiah, 1955), many of which are of the "ping-pong" type between regular partners. If this is so, a lower re-treatment rate would be expected when the treatment time with penicillin is prolonged (such has been shown to be the case-see Table VI), and also when syphilis is less common and the patient is less able to become re-infected in spite of additional sexual adventures. Certainly clinicians have been much less worried by so-called penicillin failures as the incidence of early syphilis has declined. The long-term results of penicillin in early syphilis are very good. Capiński (1961), Towpik (1961), and Perdrup (1960) have observed significant numbers of patients for 10 years or more. In Towpik's series (Table VIII) there was little change in re-treatment rates between 2 and 5 years.

The pessimists who foretold that there would be a spate of late complications after penicillin therapy can find little to justify their fears. Indeed, the expected rise in late cases consequent upon cases missed during the war years has not materialized, and in many countries late syphilis apparently pursues a downward trend.

\section{Treatment of Contacts}

In the management of venereal syphilis the treatment of contacts who have no signs of infection is still a controversial matter, and divergent views have been expressed (Willcox, 1954b; King, 1954; also Durel and Hardy, 1957; Guthe, 1958). If the sexual partner is no longer having or likely to have sexual relations with the original syphilitic patient, and if he or she could be observed clinically and serologically for 3 months, that would in theory end the matter as far as the contact is concerned. On the other hand, if the sexual union is renewed, there is a danger of "ping-pong" re-infection (Schamberg and Steiger, 1948; Prebble, 1957), and for this reason and also because venereal disease patients are notoriously prone not to follow the prescribed schedules of observation laid down for them, some clinicians prefer to treat the contacts of cases of infectious syphilis in the absence of the signs of disease just as if syphilis were known to be present, and to prescribe the same period of post-treatment observation. Deliberate treatment of contacts in the incubation period has certainly been shown to prevent the development of syphilis (Alexander and Schoch, 1949; Alexander, Schoch, and Mantooth, 1949; Plotke, Eisenberg, Baker, and Laughlin, 1949). Treatment of all or selected contacts was shown in a W.H.O. survey of port clinics in 1955 to be practised in approximately one-third of clinics-but least in Europe (Willcox and Guthe, 1957).

In the management of endemic syphilis and the other treponematoses, it has been made abundantly clear (Grin, 1953) that the simultaneous treatment of asymptomatic contacts to destroy the disease in the incubation stage and in latent cases when serum tests or individual follow-up are impracticable, is absolutely essential to the success of a mass campaign (Hackett and Guthe, 1956; Samame, 1956; Zahra, 1956; Soetopo and others, 1956; Murray and others, 1956).

\section{Reactions to Penicillin}

Reactions to penicillin may be classified as (a) toxic, (b) microbiogenic, and (c) allergic (Guthe, Idsøe, and Willcox, 1958).

(a) Toxic Reactions.-Penicillin is a remarkably non-toxic drug: the toxic dose is still many times greater than the therapeutic dose (Moore, 1947). Toxic reactions have been reported in 0.15 per cent. and less of cases (Askarov, 1959).

(b) Microbiogenic Effects.-These include therapeutic shock (Jarisch-Herxheimer reaction), and 
changes in the sensitivity of the treponeme. There are, however, no signs to date of a lessening in the sensitivity to penicillin of $T$. pallidum (Turner and Hollander, 1957), which remains an exquisitely sensitive organism. The most important microbiogenic effect in early syphilis is the Herxheimer reaction which is represented by fever and is more intense in secondary and sero-positive primary syphilis (Owsińṣka and Wasilewska, 1959; Farmer, 1948; Putkonen and Rehtijarvi, 1950; Sheldon and Heyman, 1949; Sheldon, Heyman, and Evans, 1951; Heyman, Sheldon, and Evans, 1952).

Although the evidence is not conclusive (de Graciansky, Voisin, Grupper, and Landrieux, 1951), there is some suggestion that corticosteroids may diminish or reduce the Herxheimer effect of penicillin in early syphilis (Depaoli, 1956), and cortisone has been used to prevent the Herxheimer reaction without prejudice to the outcome of treatment with penicillin (de Graciansky and Grupper, 1959). Cortisone does not, however, affect the temperature (Owsińska and Wasilewska, 1959). The Herxheimer reaction is seldom serious in early syphilis, but occasional fatalities have been reported (CzarnotaBojarska, 1953).

(c) Allergic Reactions.-The enormous literature on this subject cannot be reviewed in this paper. The common reactions have been urticaria or serum sickness-like reactions, usually mild and well controlled with antihistamines. Thus Thomas, Landy, and Cooper (1948) reported no serious reactions in over 10,000 patients treated with penicillin, and treatment had to be stopped in only two of 802 cases of syphilis treated with penicillin in oil-beeswax on account of severe urticaria. Such reactions have continued to occur sporadically.

Only two deaths from penicillin occurred in the first 9 years of its use (Kern and Wimberley, 1953). Severe cases of anaphylaxis first appeared in 1952-1953 (Kern and Wimberley, 1953; Hussar and Holley, 1954; Babione, 1956), and by 1957 over 1,000 fatalities from penicillin had occurred in the U.S.A. (Peters, Henderson, and Prickman, 1957), and they had begun to represent a legal hazard to the practitioner (Rosenthal, 1958) and might be an obstacle to the successful enforcement of a venereal disease eradication programme (Idsøe and Wang, 1958).

In venereal diseases clinics fatalities have fortunately been very uncommon (Smith, Cutler, and Pice, 1955; Morton, 1957; Willcox and Fryers, 1957; Bown, 1960), and the W.H.O. surveys (Willcox, 1958) have shown them to be very rare in relation to the enormous amounts of penicillin used, although allergic reactions of some kind may be noted in 1 per cent. of cases according to Askarov (1959) and in 15 per cent. of otherwise allergic cases (Kamdar, 1959).

An increasing awareness of the danger has been followed by a fall in these fatality rates (Welch, Lewis, Kerlan, and Putnam 1953; Welch, Lewis, Weinstein, and Boeckman, 1958). The use of penicillin has been avoided in those known or thought likely to be allergic to it (i.e. in those with a past history of upset to penicillin or of asthma) and an emergency kit containing adrenaline hydrochloride and other drugs has been available in many clinics. In the U.S.A. it is the practice to keep the patients waiting in the clinic for 30 minutes after an injection of penicillin (Brown, 1960).

Even for patients to whom it is considered unwise to administer penicillin, there are now antibiotics available which are considered more potent (and safer) than the older arsenical and bismuth drugs.

\section{Antibiotics Other than Penicillin}

Other antibiotics need to be held in reserve for patients who are known or considered likely to be sensitive to penicillin. Penicillin is undoubtedly superior, but chlortetracycline, chloramphenicol, oxytetracycline, and also tetracycline are effective, as are carbomycin (Magnamycin) and erythromycin (Montgomery and Knox, 1959a; Buckinger, Hookings, and Garson, 1955). T. pallidum is reported to be more sensitive to erythromycin and carbomycin than to other antibiotics except penicillin (Thomas, 1959), but because the tetracyclines have been available longer, there is a greater experience with their use, and also to a lesser extent with that of chloramphenicol (King, 1959; Olansky and Garson, 1958). Streptomycin is only weakly active (Willcox, 1950a).

\section{The Tetracyclines}

Although not so powerful in rabbit syphilis as penicillin (Wiggall, Zheutlin, Trice, Elmendorf, and Robinson, 1949), chlortetracycline is effective in the human disease (O'Leary, Kierland, and Herrell, 1948; Irgang and Alexander, 1948; Rodriquez, Plotke, Weinstein, and Harris, 1949; Olansky, Hogan, Taggart, Landman, and Robin, 1950; Robinson and Robinson, 1951 ; Taggart, Romansky, and Landman, 1952, and, with an appropriate dosage, results comparable with those obtained with PAM have been claimed in large series of cases (Taggart and others, 1952).

Similarly effective results have been obtained with oxytetracycline (Hendricks, Greaves, Olansky, Taggart, Lewis, Landman, Macdonald, and Welch, 
1950; Robinson, R. C. V., 1952; Robinson, H. M., 1955), and tetracycline is also apparently effective (Sannino and Ippolito, 1956; Urabe, Iwasaki, and Hara, 1955). The tetracyclines have to be given by mouth with all the disadvantages of microbiogenic effects from bacterial overgrowth. When they are given intramuscularly (Baler, 1956) or intravenously (Dunlop and Robinson, 1954), the results are unsatisfactory.

Although at one time smaller dosages were considered acceptable, these limits have now been substantially raised and the recommended dosage of the United States Public Health Service is 30 to $40 \mathrm{~g}$. tetracycline over a period of 10 to 15 days (U.S.P.H.S., 1960). This can be given as $0.75 \mathrm{~g}$. (three capsules) four times daily for 10 days (Thomas, 1959).

\section{Chloramphenicol}

This has also been shown to be effective in early syphilis in a similar dosage to that used for the tetracyclines (Romansky, Olansky, Taggart, and Robin, 1949; Robinson and Robinson, 1949; Mazzini and Blasi, 1953; Romansky, Olansky, Taggart, Landman, and Robin, 1951; Taggart and others, 1952) and results comparable to those obtained with penicillin have been claimed in large series of patients (Taggart and others, 1952). Intramuscular chloramphenicol has also been used with success by Olansky, Harb, Wood, and Rambo (1953). Chloramphenicol has not been adopted in preference to other available antibiotics because of its toxic action on bone marrow (Rich, Ritterhoff, and Hoffmann, 1950; Wolman, 1952; Hawkins and Lederer, 1952).

\section{Erythromycin}

Less erythromycin is apparently required than of the tetracyclines. Although a dose of $30 \mathrm{~g}$. given over a period of at least 8 days has been suggested (Montgomery and Knox, 1959a), cures can be obtained with less (e.g. $10 \mathrm{~g}$. over 10 days) but higher failure rates are obtained with the same amount over a shorter time (Montgomery and Knox, 1959b; Montero, 1956). The schedule recommended by the United States Public Health Service (U.S.P.H.S., 1960) is 20 to 30 g. over 10 to 15 days, but a close follow-up is urged as an adequate evaluation of these alternative antibiotics has yet to be made.

\section{Other Antibiotics}

Carbomycin (Magnamycin) is also effective in early syphilis, a total dosage of $21 \mathrm{~g}$. being necessary (Hookings and Graves, 1956).

Synnematin B has also been used in small numbers of cases of early syphilis (and also of pinta), apparently with success (Wheeler, James, Lea, and Curtis, 1957; Schwimmer and Henderson, 1959).

Kanamycin (Washburn, Garson, and Clark, 1960) and Dextrosulphenidol (Garson, Washburn, and Clark, 1960) have both been shown to be effective in rabbit, syphilis, but their toxicity is likely to preclude their general use in man.

Novobiocin (Cathomycin) is ineffective (Edelson, 1957).

\section{Penicillin in Other Forms of Syphilis}

It is not possible in this review to include the treatment of the late manifestations of syphilis, and of congenital syphilis, except for the statement that the same considerations apply and that physicians in many countries have now for more than a decade used penicillin without other drugs in all stages of the disease, deliberately avoiding the combination of penicillin with arsenic and bismuth in order to obviate the extra risks of toxicity involved.

The schedules for treatment with penicillin alone, which are recommended by the United States Public Health Service (U.S.P.H.S., 1960) for all stages of syphilis, are listed in Table XII (opposite).

The prevention of congenital syphilis by the routine serum-testing of pregnant women and the treatment with penicillin of those found to be infected is one of the triumphs of modern medicine. A comparison of the results obtained with penicillin and with other methods is shown in Table XIII, opposite (Guthe, 1958; Ingraham, 1951).

\section{Summary and Conclusions}

(1) Some of the literature on the treatment of early syphilis with penicillin is reviewed. Penicillin is the most potent antisyphilitic agent yet discovered.

(2) It is not necessarily the dose or the number of injections which determines the success or failure of penicillin in an individual case of early infectious syphilis. The decisive factor is the duration of treponemicidal penicillinaemia and, whatever the preparation or the number of injections used, such a treponemicidal penicillinaemia should be maintained for at least $\mathbf{7}$ to $\mathbf{1 0}$ days.

(3) Repository preparations-PAM and benzathine penicillin - are best in this regard, since penicillinaemia of adequate duration can be obtained with a single injection, or with a few, depending upon the size of the dose and the spacing of the injections. 
TABLE XII

SCHEDULES FOR TREATMENT WITH PENICILLIN ALONE RECOMMENDED BY UNITED STATES PUBLIC HEALTH SERVICE (U.S.P.H.S., 1960)

\begin{tabular}{|c|c|c|c|c|c|c|c|c|}
\hline \multirow[b]{2}{*}{ Stage of Syphilis } & \multirow[b]{2}{*}{. } & \multirow[b]{2}{*}{$\ldots$} & \multirow[b]{2}{*}{. } & \multicolumn{2}{|c|}{ Acquired } & \multicolumn{3}{|c|}{ Congenital } \\
\hline & & & & $\begin{array}{l}\text { Early (Primary, } \\
\text { Secondary, } \\
\text { and Latent) }\end{array}$ & $\begin{array}{c}\text { Late } \\
\text { (All Other Forms) }\end{array}$ & Early & & Late \\
\hline \multirow{3}{*}{ Preparation } & $\begin{array}{l}\text { Aqueous } \\
\text { Procaine } \\
\text { Penicillin }\end{array}$ & & $\begin{array}{l}\text { Dose (mega units) } \\
\text { Injections } \\
\text { Days } \quad .\end{array}$ & $\begin{array}{l}4 \cdot 8 \\
8 \\
8\end{array}$ & $\begin{array}{r}6-9 \\
10-15 \\
10-15\end{array}$ & - & $\begin{array}{l}\text { If } \\
\text { fluid } \\
\text { as for }\end{array}$ & $\begin{array}{l}\text { cerebrospinal } \\
\text { non-reactive, } \\
\text { latent syphilis }\end{array}$ \\
\hline & PAM & & $\begin{array}{l}\text { Dose (mega units) } \\
\text { Injections } \\
\text { Days } \quad .\end{array}$ & $\begin{array}{l}4 \cdot 8 \\
3 \\
6\end{array}$ & $\begin{array}{l}6-9 \cdot 6 \\
4-8 \\
9-18\end{array}$ & $\begin{array}{c}100,000 \mathrm{u} / \mathrm{kg} . \\
3 \\
6\end{array}$ & $\begin{array}{l}\text { If } \\
\text { fluid } \\
\text { for }\end{array}$ & $\begin{array}{r}\text { cerebrospinal } \\
\text { reactive, as } \\
\text { neurosyphilis }\end{array}$ \\
\hline & $\begin{array}{l}\text { Benzathine } \\
\text { Penicillin }\end{array}$ & & $\begin{array}{l}\text { Dose (mega units) } \\
\text { Injections } \\
\text { Days } \quad .\end{array}$ & $\begin{array}{l}2 \cdot 4^{*} \\
1 \\
1\end{array}$ & $\begin{array}{l}6-9 \\
2-3 \\
7-14\end{array}$ & $\begin{array}{c}50,000 \mathrm{u} / \mathrm{kg} \\
1 \\
1\end{array}$ & & \\
\hline
\end{tabular}

* Dose doubled in latent syphilis if cerebrospinal fluid not known to be negative. (All doses in mega units).

TABLE XIII

OUTCOME OF PREGNANCY AND EFFECT OF ADEQUATE PREVENTIVE TREATMENT IN THE PREGNANT SYPHILITIC MOTHER (Guthe, 1958)*

\begin{tabular}{|c|c|c|c|c|c|c|c|c|c|c|}
\hline & \multirow{3}{*}{\multicolumn{4}{|c|}{ Outcome of Pregnancy }} & & & \multicolumn{4}{|c|}{ Mother } \\
\hline & & & & & & & \multirow{2}{*}{$\begin{array}{l}\text { Non-syphilitic } \\
\text { (Per cent.) }\end{array}$} & \multirow{2}{*}{$\begin{array}{l}\text { Untreated } \\
\text { Syphilitic } \\
\text { (Per cent.) }\end{array}$} & \multicolumn{2}{|c|}{ Treated for Early Syphilis (per cent.) } \\
\hline & & & & & & & & & $\begin{array}{c}\text { Arsenic and } \\
\text { Bismuth }\end{array}$ & Penicillin \\
\hline Living Infant & $\begin{array}{l}\text { Norm } \\
\text { Syphil } \\
\text { Prema } \\
\text { Full-t } \\
\text { Prema }\end{array}$ & $\begin{array}{l}\text { al ful } \\
\text { itic } \\
\text { ture } \\
\text { erm } \\
\text { ture }\end{array}$ & $\begin{array}{l}\text { erm } \\
\cdots \\
\text { n-sy } \\
\cdots \\
\cdots\end{array}$ & $\begin{array}{l}\ldots \\
\text { ilitic } \\
\ldots \\
\ldots\end{array}$ & $\begin{array}{l}\cdots \\
\cdots \\
\cdots \\
\cdots\end{array}$ & $\begin{array}{l}\cdots \\
\cdots \\
\cdots \\
\cdots\end{array}$ & $\begin{array}{c}86 \cdot 3 \\
\overline{9 \cdot 0} \\
0 \cdot 5 \\
1 \cdot 7\end{array}$ & $\begin{array}{r}18 \cdot 2 \\
40 \cdot 9 \\
2 \cdot 3 \\
1 \cdot 8 \\
11 \cdot 8\end{array}$ & $\begin{array}{r}91.4 \\
2.2 \\
0.7 \\
1.9 \\
0.0\end{array}$ & $\begin{array}{r}94.0 \\
1.1 \\
0.4 \\
0.2 \\
0.9\end{array}$ \\
\hline \multicolumn{2}{|c|}{ Stillborn full-term } & . & $\cdots$ & . & . & $\cdots$ & $0 \cdot 5$ & $18 \cdot 2$ & $3 \cdot 4$ & $2 \cdot 3$ \\
\hline \multicolumn{2}{|c|}{ Premature (miscarriage) } & . & . & . & . & $\cdots$ & $2 \cdot 1$ & $6 \cdot 8$ & 0.4 & $1 \cdot 1$ \\
\hline
\end{tabular}

* Based on data from Ingraham (1951).

Some results of the use of these preparations in the treatment of early syphilis are tabulated.

(4) Considerable variations have been found between different PAM preparations as regards the duration of the penicillinaemia. The international minimal requirements established by W.H.O. should be met when PAM is used for the treatment of syphilis.

(5) The addition of arsenic and/or bismuth to penicillin offers no advantages and carries the additional risks of serious toxic side-effects.

(6) The results of a W.H.O. survey of treatment practices are given. The new concepts of treatment which resulted from the introduction of penicillin were accepted more slowly in Europe than in other parts of the world.
(7) Many of the so-called treatment "failures" with penicillin were in fact re-infections.

(8) The treatment of contacts, so essential in the mass treatment of the endemic treponematoses, has been shown by W.H.O. surveys to be practised to some extent in cases of venereal syphilis in approximately one-third of the clinics surveyed.

(9) While the toxic dose of penicillin is still far above the therapeutic dose, allergic reactions sometimes occur. These can largely be avoided by not giving penicillin to allergic patients or to those who seem likely to be sensitive to penicillin.

(10) The results of treating syphilis with other antibiotics are reviewed. Although penicillin is the best, the tetracyclines and erythromycin are recommended for patients known or thought to be allergic to penicillin. 


\section{REFERENCES}

Agneta, J. O., and Molina, E. B. (1955). Rev. argent. Dermatosif., 39, 29.

Aitken, R. B. (1947). J. vener. Dis. Inform., 28, 224.

Alechinsky, A. (1949). Arch. belges Derm., 5, 100.

Alexander, L. J., and Schoch, A. G. (1949). Arch. Derm. Syph. (Chicago), 59, 1.

,$- \frac{1}{33,}$ and Mantooth, W. B. (1949). Amer. J. Syph., 33, 429 .

,--1 (1950). Ibid., 34, 420.

Altshuler, L., Karpinos, B. D., Leifer, W., and Ozog, J. J. (1949). Ibid., 33, 126.

Arnold, R. C., Boak, R. A., Carpenter, C. M., Chesney, A. M., Fleming, W. L., Gueft, B., Mahoney, J. F., and Rosahn, P. D. (1947a). Ibid., 31, 469.

_-, Mahoney, J. F., Cutler, J. C., and Levitan, S. (1947b). J. invest. Derm., 9, 269.

Arutyunov, V. Y., and Gurvich, E. I. (1958). Vestn. Derm. Vener., 32, No. 2, p. 57.

- , - and Ilina, A. V. (1948). Ibid., 22, No. 6, p. 11.

Askarov, U. A. (1959). Ter. Arh., 31, 32.

Aufranc, W. H., and Price, E. V. (1951). Amer. J. Syph., $35,57$.

Babione, R. W. (1956). Antibiot. Med., 3, 388.

Baler, G. R. (1956). A.M.A. Arch. Derm., 73, 489.

Barbosa Ribas, E., Marquesini, O., Russo, A., van Erven, B., Capriglione, O., and Pizzato, A. (1955). Hospital (Rio de J.), 48, 493.

Batunin, M. P., Kagan, M. Z., Mikhailov, K. A., Nosyreva, N. N., and Khizkin, V. Yu. (1959). Vestn. Derm. Vener., 33, No. 5, p. 50.

Bauer, T. J., Bundesen, H. N., Craig, R. M., Schwemlein, O. X., and Barton, R. L. (1947). Amer. J. Syph., $31,45$.

Usilton, L. J., and Price, E. V. (1950). J. vener. Dis. Inform., 31, 65.

Beerman, H., and Wammock, V. S. (1947). Amer. J. Syph., $31,150$.

Belden, E. A. (1956). Missouri Med., 53, 1072.

Belenkii, G. B. (1959). Vestn. Derm. Vener., 33, No. 4, p. 46.

Bellone, A. G. (1947). G. ital. Derm. Sif., 88, 552.

Bolgert, M., and Lévy, G. (1957a). Bull. Soc. franç. Derm. Syph., 64, 31.

-

Bowden, P. W., and Holmes, E. M. (1950). Va med. Monthly, 77, 285.

Brown, W. J. (1960). Brit. J. vener. Dis., 36, 30.

Buckinger, R. H., Hookings, C. E., and Garson, W. (1955). Antibiot. Med., 1, 100.

Buckwalter, F. H., and Dickison, H. L. (1948). J. Amer. pharm. Ass. (Sci. ed.), 37, 472.

Burckhardt, W. (1949). Dermatologica (Basel), 99, 273.

Capiński, T.Z. (1961). Personal communication to W.H.O.

Carpenter, C. M., Boak, R. A., and Jacobs, L. M. (1946). N.Y.St.J.Med., 46, 2150

Carrera, J. L. (1955a). Sem. méd., 107, 722.

(1955b). Rev. argent. Dermatosif., 39, 37.

Castro, N. O., and Bonatti, A. A. (1957). Arch. argent. Derm. 7, 61 .

Chargin, L., Sobel, N., Rein, C., and Rosenthal, T. (1949). Arch. Derm. Syph. (Chicago), 59, 595.

,- , and Rosenthal, T. (1951). A.M.A.Arch. Derm. Syph., 63, 104.

Chope, H. D., and Malcolm, J. C. (1948). J. vener. Dis. Inform., 29, 173.

Cormia, F. E., and Blauner, S. G. (1947). Amer. J. Syph., $31,135$.
Cumberland, M. C., and Turner, T. B. (1949). Ibid., 33, 201.

Cutler, J. C., Olansky, S., and Price, E. V. (1955). A.M.A. Arch. Derm. Syph., 71, 239.

Czarnota-Bojarska, M. (1953). Pol. Tyg. lek., 8, 1518.

Czernielewski, A., and Olszewska, Z. (1961). Personal communication to W.H.O.

Danbolt, N. (1954). T. norske Laegeforen., 74, 301.

- , and Berdal, T. (1950). Acta derm.-venereol.(Stockh.), 30, 354.

Degos, R., Garnier, G., and Delzant, O. (1958). Bull. Soc. franc. Derm. Syph., 65, 577.

Vissian, L., and Basset, H. (1950). Ann. Derm. Syph. (Paris), 8 sér., 10, 497.

de Graciansky, P., and Grupper, C. (1959). Bull. Soc. franc. Derm. Syph., 66, 699.

Voisin, J., Grupper, C., and Landrieux, P. (1951). Ibid., 58, 574.

Depaoli, M. (1956). Minerva derm. (Torino), 31, 263.

des Roseaux, J. (1949). Rev. Méd. nav. 4, 111.

Dexter, D. D. (1947). Amer. J. Syph., 31, 533.

Döllken, H. (1954). Z. Haut-u. Geschl.-Kr., 17, 46.

Downing, C. C. R. (1950). Brit. J. vener. Dis., 26, 31

Dunlop, E. M. C., and Robinson, R. C. V. (1954). Amer. J. Syph., 38, 24.

Durel, P., and Hardy, N. (1957). Rev. Hyg. Méd. soc., 5, 219.

Eagle, H. (1948). Ann. intern. Med., 28, 260.

and Magnuson, H. J. (1946). Amer.J. Syph., 30, 420.

Eames, J. W., and Archer, G. T. L. (1947). J. roy. Army med. Cps, 89, 57.

_ and Miller, D. H. (1949). Brit. med. J., 2, 672.

Edelson, E. (1957). Antibiot. Med., 4, 725.

Edmunds, A. W. B. (1954). Brit. J. vener. Dis., 30, 45.

Farmer, T. W. (1948). J. Amer. med. Ass., 138, 480.

Fazekas, I. G., and Dósa, A. (1954). Arch. Derm. Syph. (Berl.), 197, 436.

Feldreich,H.(1956). Acta derm.-venereol.(Stockh.),36, 291

Foldväri, F. (1961). Personal communication to W.H.O.

Gallego, E. (1956). “Antibiotics Annual, 1955-56”, p. 816.

Garson, W., Washburn, T. C., and Clark, J. W. (1960). “Antibiotics Annual, 1959-60”, p. 472.

Gault, E. L. (1955). J. Christ. med. Ass. India, 30, 110.

Gay Prieto, J., Alvarez Cascos, M., and Orusco, M. (1953). Act. dermo-sifiliogr. (Madr.), 44, 483.

Grin, E. (1953). "Epidemiology and Control of Endemic Syphilis: Report on a Mass Treatment Campaign in Bosnia." World Health Organization: Monograph Series, No. 11. W.H.O., Geneva. (1956). Bull. Wld Hith Org., 15, 959.

Gurevich, Y. K., Kamenetski, I. S., and Litvak, P. L. (1958). Vestn. Derm. Vener., 32, No. 4, p. 42.

Guthe, T. (1958). Bull. Wld Hlth Org., 19, 405.

, Idsøe, O., and Willcox, R. R. (1958). Ibid., 19, 427. and Willcox, R. R. (1954). Chron. Wld Hlth Org., 8, 37.

Hackett, C. J., and Guthe, T. (1956). Bull. Wld Hlth Org., $15,869$.

Harrison, L. W. (1945). Practitioner, 155, 223.

Hasselmann, C. M. (1949). Med. Klin., 44, 657.

Hawkins, L. A., and Lederer, H. (1952). Brit. med. J., 2, 423 .

Hayman, C. R. (1947). J. vener. Dis. Inform., 28, 221.

Heller, J. R. (1946). Ibid., 27, 217. , Bowman, R. W., and Price, E. V. (1948). Ibid., 29, 103.

Helmeczi, L., Máramarosi, G., and Fekete, Z. (1955). Ther. hung., No. 1 , p. 10 . 
Hendricks, F. D., Greaves, A. B., Olansky, S., Taggart, S. R., Lewis, C. N., Landman, G. S., MacDonald, G. R., and Welch, H. (1950). J. Amer. med. Ass., 143, 4 .

Heyman, A., Sheldon, W. H., and Evans, L. D. (1952). Brit. J. vener. Dis., 28, 50.

Höfer, W., and Heilmann, P. (1953). Arch. Derm. Syph. (Berl.), 195, 331.

Hookings, C. E., and Greaves, L. M. (1956). Paper presented at First International Symposium on Venereal Diseases and Treponematoses, Washington, D.C. Curr. Lit. vener. Dis., p. 11.

Hume, J. C., and Facio, G. (1956). Bull. Wld Hlth Org., $15,1057$.

Huriez, C. (1956). Paper presented at First International Symposium on Venereal Diseases and Treponematoses, Washington, D.C.

Hussar, A. E., and Holley, H. L. (1954). "Antibiotics and Antibiotic Therapy: Clinical Manual." Macmillan, New York.

Idsøe, O., Guthe, T., Christiansen, S., Krag, P., and Cutler, J. C. (1954). Bull. Wld Hith Org., 10, 507. and Wang, K. Y. (1958). Ibid., 18, 323.

Ingraham, N. R. (1951). Acta derm.-venereol. (Stockh.), 31, Suppl. 24, p. 60.

Irgang, S., and Alexander, E. R. (1948). Harlem Hosp. Bull., 1, 91 .

Jefferiss, F. J. G., Willcox, R. R., and McElligott, G. L. M. (1951). Lancet, 1, 83 .

Jones, E. H. (1951). Ohio St. med. J., 47, 131.

Jones, R. W., and Heyman, A. (1952). Amer. J. Syph., 36, 250.

Kamdar, N. R. (1959). Indian Practit., 12, 17.

Kapuściński, S. (1950). Panstw. Zaklad. Wyd. Lek. W-Wa (1950), p. 144.

Kern, R. A., and Wimberley, N. A. (1953). Amer. J. med. Sci., 226, 357.

Khokhutin, I. I. (1956). Vestn. Vener. Derm., 30, No. 3, p. 32.

Kinaçigil, R. T. (1956). Paper presented at First International Symposium on Venereal Diseases and Treponematoses, Washington, D.C. Curr. Lit. vener. Dis., p. 12.

King, A. J. (1954). Brit. J. vener. Dis., 30, 13.

(1959). Brit. med. J., 1, 431.

Krugman, S., and Ebin, E. V. (1958). Pediatrics, 21, 243.

Laird, S. M. (1946). Brit. J. vener. Dis., 22, 29.

Landy, S., Rein, C. R., and Thomas, E. W. (1956). Paper presented at First International Symposium on Venereal Diseases and Treponematoses, Washington, D.C. Curr. Lit. vener. Dis., p. 14. $-, \frac{1}{\text { Org., 16, }}, \frac{154 \text {. }}{-}$ and Kelcec, L. L. (1957). Bull. Wld Hlth

Langer, E., and Krüger, H. (1952). Z. Haut-u. Geschl.-Kr., 13, 321 .

Leavitt, H. M. (1947). Amer. J. Syph., 31, 27.

Lebioda, J. (1951). Panstw. Zaklad. Wyd. Lek. W-Wa (1951), p. 82.

and Winiarski, J. (1961). Personal communication to W.H.O.

Lejman, K., Bittner-Korturkowa, D., and LogdaszewskaCzabanowska, J. (1961). Personal communication to W.H.O.

Le Loutre, R. (1955). Maroc méd., 34, 561.

Lesinska, W. M. (1961). Personal communication to W.H.O.

Levaditi, C., and Vaisman, A. (1950). Presse méd., 58, 1397.
López, B., and Rodriguez Morales, J. (1955). Act. dermosifiliogr. (Madr.), 46, 562.

Loza, E. (1950). Panstw. Zaklad. Wyd. Lek. W-Wa(1950), p. 25.

Lozano, A. A. (1950). J. Philipp. med. Ass., 26, 75.

McElligott, G. L. M. (1948). Brit. J. vener. Dis., 24, 9.

—, Jefferiss, F. J. G., and Willcox, R. R. (1948). Ibid., 24, 45 .

and Willcox, R. R. (1957). W.H.O. Working Document WHO/VDT/232.

Magnuson, H. J. (1952). Ann. N. Y. Acad. Sci., 55, 1161.

, Eagle, H., and Fleischman, R. (1948). Amer.J. Syph., 32, 1 .

_- and Rosenau, B. J. (1948). Ibid., 32, 203.

Mahoney, J. F., Arnold, R. C., and Harris, A. (1943a). J. vener. Dis. Inform., 24, 355.

,,-- (1943b). Amer. J. publ. Hlth, 33, 1387.

__ (1949). J. vener. Dis. Inform,. 30, 350.

Maillard, E. R., and Orzel, A. (1946). Amer. J. Syph., 30, 490.

Marin, A., Boulais, F. L., Lambert, A., Foisy, J. P., and Leclerc, G. (1949). Ann. Derm. Syph. (Paris), 8 sér., 9, 23.

Matveev, V. N., Khaimovsky, D. I., Levinstein, M. V., and Abdullaev, A. K. (1959). Vestn. Derm. Vener., 33, No. 5 , p. 59.

Mazzini, M. A., and Blasi, A. A. (1953). Rev. argent. Dermatosif., 37, 114.

Montero, O. (1956). Paper presented at First International Symposium on Venereal Diseases and Treponematoses, Washington, D. C. Curr. Lit. vener. Dis., p. 19.

Montgomery, C. H., and Knox, J. M. (1959a). New Engl. J. Med., 261, 277.

_- (1959b). A.M.A. Arch. Derm., 80, 205.

Moore, J. E. (1943). "Modern Treatment of Syphilis." Thomas, Springfield, Ill.

- (1947). "Penicillin in Syphilis." Thomas, Springfield, IIl.

(1948). Brit. J. vener. Dis., 24, 1.

Morton, R. S. (1948). Brit. med. J., 2, 938.

(1957). Brit. J. vener. Dis., 33, 176.

Murray, J. F., Merriweather, A. M., and Freedman, M. L. (1956). Bull. Wld Hlth Org., 15, 975.

Neering, K. E. H. P. (1948). Ned. T. Geneesk., 92, 1145.

Nielsen, H. A. (1961). INT/VDT/156. Paper presented to the W.H.O. Venereal Disease Travelling Seminar in the U.S.S.R.

O'Brien, J. F., and Smith, C. A. (1952). Amer. J. Syph., 36, 519.

Olansky, S., and Garson, W. (1958). A.M.A. Arch. Derm., 77, 648.

, Harb, F. W., Wood, C. E., and Rambo, D. S. (1953). Amer.J. Syph., 37, 253.

, Hogan, R. B., Taggart, S. R., Landman, G. S., and Robin, E. D. (1950). Ibid., 34, 436.

and Putnam, L. E. (1946). J. vener. Dis. Inform., 27, 178.

O'Leary, P. A., Kierland, R. R., and Herrell, W. E. (1948). Proc. Mayo Clin., 23, 574.

O'Malley, C. K. (1950). S. Afr. med. J., 24, 127.

Ovchinnikov, H. M. (1955). "Experimental Syphilis." Medgiz, Moscow.

- and Kuchinskaya, E. P. (1948). Vestn. Vener. Derm., 22, No. 6, p. 20.

Owsińska, I., and Wasilewska, H. (1959). Przegl. Derm. Wener., 46, 363.

Pardo, O. A. (1956). Bol. Soc. cuba. Derm. Sif., 13, 35. 
and Pardo Castello, V. (1952). Amer. J. Syph., 36, 342.

Parkhurst, G. E., Weinstein, S., and Rodriquez, J. (1952). Ibid., 36, 258.

Parnitzke, K. H., and Döhner, W. (1950). Dtsch. med. Wschr., 75, 262.

Pawlas, R., and Golebiowska, I. (1950). Panstw. Zaklad. Wyd. Lek. W-Wa (1950), p. 216.

Peabody, G. E., and Webster, B. (1949). Amer. J. Syph., 33, 334.

Perdrup, A. (1950). Ugeskr. Laeg., 112, 1089.

- (1960). Acta derm.-venereol. (Stockh.), 40, 340.

and Heilesen, B. (1956). Paper presented at First International Symposium on Venereal Diseases and Treponematoses, Washington, D.C. Curr. Lit. vener. Dis., p. 22.

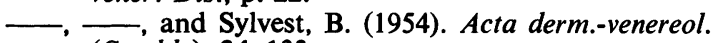
(Stockh.), 34, 133.

Peters, G. A., Henderson, L. L., and Prickman, L. E. (1957). Ann. Allergy, 15, 135.

Pietrowska, J. Cited by Zahra (1956).

Pillsbury, D. M., and Loveman, A. B. (1947). Amer. J. Syph., 31, 115.

Pirilä, V. (1949). Ann. Med. intern. Fenn., 38, 177.

Plotke, F., Eisenberg, H., Baker, A. H., and Laughlin, M. E. (1949). J. vener. Dis. Inform., 30, 252.

Rodriquez, I., and Schwemlein, G. X. (1951). Amer. J. Syph., 35, 240.

Prebble, E. E. (1946). Brit. J. vener. Dis., 22, 93. (1957). Ibid., 33, 112.

Prochacki, H. (1953). Przegl. Derm. Wener., 3, 328.

-, Smolska, B., Dobosiewicz, E., Hawryluk, L., and Tarchalska, E. (1961). Personal communication to W.H.O.

Putkonen, T., and Rehtijärvi, K. (1950). Acta derm.venereol. (Stockh.), 30, 503.

Rajam, R. V., Krishnamurthi, N., and Rangiah, P. N. (1955). J. Indian med. Ass., 25, 115.

Rein, C. R., Kitchen, D. K., Marquez, F., and Varela, G. (1952). J. invest. Derm., 18, 137.

Reymann, F. (1948). Acta derm.-venereol. (Stockh.), 28, 238.

Rich, M. L., Ritterhoff, R. J., and Hoffmann, R. J. (1950). Ann. intern. Med., 23, 1459.

Rider, R. V. (1949). Amer. J. Syph., 33, 19.

Robinson, H. M. (1955). Int. Rec. Med., 168, 207.

and Robinson, H. M. Jr (1949). Sth. med. J. (Bgham, Ala.), 42, 988.

- (1951). Amer. J. Syph., 35, 479.

Robinson, R. C. V. (1952). Brit. J. vener. Dis., 28, 80.

Rodriquez, J., Plotke, F., Weinstein, S., and Harris, W. W. (1949). J. Amer. med. Ass., 141, 771.

- Schwemlein, G. X., and Plotke, F. (1951). Amer. J. Syph., 35, 246.

Rollier, R. (1957). Maroc méd., 36, 827.

Romansky, M. J., Olansky, S., Taggart, S. R., Landman, G. S., and Robin, E. D. (1951). Amer. J. Syph., 35, 234.

$\longrightarrow, \frac{234}{639},-$, and Robin, E. D. (1949). Science, 110,

and Rein, C. R. (1946). J. Amer. med. Ass., 132, 847.

- and Rittman, G. E. (1945). New Engl. J. Med., 233, 577.

Rosenthal, A. (1958). J. Amer. med. Ass., 167, 1118.

Rosner, J. (1950). Panstw. Zaklad. Wyd. Lek. W-Wa (1950), p. 157

Rozentul, M. A., Vasilev, T. V., Egorow, G. I., Maslov, P. E., Khamaganova, A. V., and Rakhmanova, N. V. (1961). Sovetsk. Med., 25, 105.
Ryll-Nardzewski, C. Z. (1950). Panstw. Zaklad. Wyd. Lek. $W-W a(1950)$, p. 236.

Sackett, A. P., and Boggs, H. (1949). J. vener. Dis. Inform., 30, 219.

Salaman, M. H., King, A. J., Williams, D. I., and Nicol, C. S. (1944). Lancet, $2,7$.

Samame, G. E. (1956). Bull. Wld Hlth Org., 15, 897.

Sannino, M., and Ippolito, F. (1956). Minerva med. (Torino), [Parte Sci], 47 (1), 1427.

Schamberg, I. L. (1950). Amer. J. Syph., 34, 73.

— and Steiger, H. P.(1948). J. vener. Dis. Inform., $29,92$.

Schmidt-La Baume, F., and Thélen, C. (1953). Z. Haut-u. Geschl.-Kr., 15, 140.

Schoch, A. G., and Alexander, L. J. (1949). Arch. Derm. Syph. (Chicago), 60, 690.

Schoog, M. (1949). Med. Klin., 44, 329.

Schwemlein, G. X., Plotke, F., and Rodriquez, J. (1950). J. vener. Dis. Inform., 31, 155.

Schwimmer, B., and Henderson, N. D. (1959). Brit. J. vener. Dis., 35, 258.

Shafer, J. K., and Smith, C. A. (1954). Bull. Wld Hlth Org., $10,619$.

Usilton, L. J., and Price, E. V. (1954). Bull. Wld Hlth Org., 10, 563.

Sheldon, W. H., and Heyman, A. (1949). Amer. J. Syph., 33, 213.

and Evans, L. D. (1951). Ibid., 35, 411.

Smelov, N. S. (1956). Paper presented at First International Symposium on Venereal Diseases and Treponematoses, Washington, D.C. (1957). Brit. J. vener. Dis., 33, 16.

Smith, C. A., Cutler, J. C., and Price, E. V. (1955). "Antibiotics Annual, 1954-55”, pp. 144, 361.

Kamp, M., Olansky, S., and Price, E. V. (1956). Bull. Wld Hlth Org., 15, 1087.

O'Brien, J. F., Simpson, W. G., Harb, F. W., and Shafer, J. K. (1954). Amer. J. Syph., 38, 136.

Sokolowski, F. (1950). Panstw. Zaklad. Wyd. Lek. W-Wa (1950), p. 164

Soetopo, M., Wasito, R., Soedarsono, H., and Tjokrodipo, D. (1956). Bull Wld Hlth Org., 15, 937.

Sternberg, T. H., and Leifer, W. (1947a). J. Amer. med. Ass., 133, 1.

- - (1947b). Amer. J. Syph., 31, 124.

Stokes, J. H., Beerman, H., and Ingraham, J. H. (1944). "Modern Clinical Syphilology", 3rd ed., p. 212. Saunders, Philadelphia.

Taggart, S. R., Hendricks, F. D., Chandler, V. L., Welch, H., Harley, D. H., and Olansky, S. (1949). Amer.J. Syph., 33, 515.

-, Romansky, M. J., and Landman, G. S. (1962). Ibid., 36, 174.

Tempski, J., and Olszewska, Z. (1954). Pol. Tyg. lek., 9, 805.

Thomas, E. W. (1947). N.Y. St. J. Med., 47, 2439.

(1948a). Amer.J. Med., 5, 687.

(1948b). Amer. J. publ. Hlth, 38, 1361.

(1959). Ariz. Med., 16, 420.

and Gleesen, G. A. (1953). Amer. J. Syph., 37, 458. and Landy, S. (1950). Ibid., 34, 126.

28, and Cooper, C. (1947). J. vener. Dis. Inform., 28, 19.

—,$~-~-~(1948)$. J. invest. Derm., 10, 77

, Rein, C. R., and Kitchen, D. K. (1949). Amer. J. Syph., 33, 523.

, Landy, S., and Kitchen, D. K. (1950). Ibid., 34, 331 . (1951). Ibid., 35, 475 . 
Thompson, R. G., and Smith, D. C. (1950). Ibid., 34, 410.

Towpik, J. (1950). Panstw. Zaklad. Wyd. Lek. W-Wa (1950), p. 173.

(1956). Panstw. Zaklad. Wyd. Lek. W-Wa (1956), p. 78.

(1961). Personal communication to W.H.O.

Turner, T. B., Cumberland, M. C., and Huan-Ying Li (1947). Amer. J. Syph., 31, 476.

_- and Hollander, D. H. (1957). "Biology of the Treponematoses." World Health Organization: Monograph Series No. 35. W.H.O., Geneva.

Urabe, H., Iwasaki, H., and Hara, T. (1955). Kyusha J. med. Sci., 6, 159.

United States Public Health Service (1946). J. Amer. med. Ass., 131, 271.

(1960). "Syphilis: Modern Diagnosis and Management." U.S. Department of Health, Education and Welfare, Washington, D.C.

Veyre, P., and Baylet, R. (1949). Méd. trop., 9, 213.

Vilanova, X., and Alvarado, L. (1953). Act. dermo-sifiliogr. (Madr.), 44, 509.

Walker, A. E., and Utterback, M. (1949). Arch. Derm. Syph. (Chicago), 59, 277.

Walter, F., Capiński, Z., Lejman, K., and Lebioda, J. (1950). Panstw. Zaklad. Wyd. Lek. W-Wa (1950), p. 83 .

Washburn, T. C., Garson, W., and Clark, J. W. (1960). "Antibiotics Annual, 1959-60", pp. 478-483.

Weiner, A. L. (1947). Cincinn. J. Med., 28, 301.

Welch, H., Lewis, C. N., Kerlan, L., and Putnam, L. E. (1953). Antibiot. and Chemother., 3, 891.

,-- Weinstein, H. C., and Boeckman, B. B. (1958). "Antibiotics Annual, 1957-58", p. 296.

Wheeler, A. H., James, K., Lea, W., and Curtis, A. C (1957). A.M.A. Arch. Derm., 76, 735.

Wiggall, R. H., Zheutlin, H. E. C., Trice, E. R., Elmendorf, D. F., and Robinson, R. C. V. (1949). Amer. J. Syph., 33, 416.

Willcox, R. R. (1947). Brit. J. vener. Dis., 23, 121.

(1950a). J. vener. Dis. Inform., 31, 254.

(1950b). Lancet, 1, 396.

(1954a). Bull. Wld Hlth Org., 10, 579.

(1954b). Brit. J. Vener. Dis., 30, 7.

(1958). Bull. Wld Hlth Org., 18, 457.

(1961). INT/VDT/156. Paper presented to the W.H.O. Venereal Disease Travelling Seminar in the U.S.S.R.

— and Fryers, G. R. (1957). Brit. J. vener. Dis., 33, 209.

- and Guthe, T. (1957). Bull. Wld Hlth Org., 16, 1033.

Wolman, B. (1952). Brit. med. J., 2, 426.

World Health Organization (1953). "Expert Committee on Venereal Infections and Treponematoses, Fourth Report." Wld Hlth Org. tech. Rep. Ser., 63.

Wright, R. D., Nicholson, F. P., and Arnold, R. C. (1950). J. vener. Dis. Inform., 31, 235.

Zahra, A. (1956). Bull. Wld Hlth Org., 15, 911.
Traitement antibiotique de la syphilis vénérienne précoce

RÉSUMÉ

(1) On passe en revue une grande partie de la littérature dès l'inception du traitement de la syphilis précoce par la pénicilline, remède qui reste la plus puissante arme contre cette condition.

(2) Ce n'est ni le volume de la dose ni le nombre des injections qui réussit à guérir un malade particulier. Le facteur décisif est la durée de la pénicillinémie tréponémicide, et quel que soit le régime employé, il faut maintenir ce niveau pour au moins 7 à 10 jours.

(3) Les préparations retard (PAM et pénicilline benzathine) sont les meilleures, parce qu'une seule injection (ou bien un petit nombre d'injections selon le volume et la fréquence de la dose) assure une pénicillinémie assez prolongée. On cite quelques résultats obtenus avec ces préparations.

(4) La durée de la pénicillinémie obtenue avec les différentes préparations commerciales de PAM varie beaucoup. La spécification internationale minimale établie par l'O.M.S. doit être observée quand le PAM est employé contre la syphilis.

(5) Il n'y a aucune raison d'ajouter ni l'arsenic ni le bismuth à la pénicilline, et ces substances apportent en outre l'hasard de la toxicité.

(6) Une revue du traitement entrepris par l'O.M.S. indique que les nouvelles idées introduites par la découverte de la pénicilline furent adoptées plus lentement en Europe qu'ailleurs.

(7) Plusieurs "échecs" du traitement avec la pénicilline étaient dus en effet à une infection récidive.

(8) Des revues entreprises par l'O.M.S. indiquent que l'investigation des consorts sexuels, si nécessaire dans le traitement en masse des tréponématoses endémiques, est pratiquée plus ou moins complètement dans un tiers des cliniques étudiées.

(9) Tandis que la dose toxique de pénicilline reste beaucoup plus grande que la dose thérapeutique, les réactions allergiques se voient de temps en temps. Ces réactions inattendues n'arriveront pas si l'on ne donne pas de pénicilline aux sujets hypersensibles.

(10) On passe en revue les autres antibiotiques qui ont été employés contre la syphilis. La pénicilline est la meilleure, mais les tétracyclines, l'érythromycine, et la carbomycine peuvent être données aux sujets hypersensibles. 